\title{
The (Uncertain) Impact of Brexit on the United Kingdom's Membership in the European Economic Area
}

\author{
ULRICH G. SCHROETER* AND HEINRICH NEMECZEK**
}

\section{Introduction}

Until recently, the on-going legal discussions about 'Brexit', the United Kingdom's upcoming withdrawal from the European Union (EU), have predominantly focused on the requirements and consequences of the withdrawal procedure set out in Article 50 of the Treaty on European Union (TEU) ${ }^{1}$. A hitherto neglected, though arguably no less important question concerns the effect, if any, that a withdrawal from the EU will have on the UK's membership in the European Economic Area (EEA)2: Given that the EEA extends many aspects of EU membership beyond the EU's borders, resulting in a Common Market 'light', a future UK membership in the EEA could - at least from a European business law point of view - effectively result in 'business as usual', as a significant share of EU law would continue to apply to UK companies, albeit in form of EEA law.

Against this background, it is interesting to note that legal analyses of Brexit generally assume that the UK's EEA membership will be terminated ipso iure, should the UK decide to withdraw from the EU. ${ }^{3}$ According to this view, the UK subsequently could (re-)apply for EEA membership should its government so choose, with such an application having to be accepted by all remaining EEA Contracting Parties - an option commonly referred to as the 'Norway option'4 in reference to Norway's

\footnotetext{
* Professor of Law at the University of Mannheim (Germany), Chair for Private Law, International Corporate and Financial Markets Law, European Business Law.

** Attorney-at-law, research fellow at the University of Mannheim (Germany), Chair for Private Law, International Corporate and Financial Markets Law, European Business Law.

${ }^{1}$ OJ C 326, 26 October 2012, 1.

2 On the EEA, see in more detail below at 2 .

${ }^{3}$ See, inter alia, House of Commons Library, Research Paper 13/42, 19; Marc-Philippe Weller, Chris Thomale and Nina Benz, Englische Gesellschaften und Unternehmensinsolvenzen in der PostBrexit-EU, Neue Juristische Wochenschrift 2380 (2016); The Law Society of England and Wales, The EU and the Legal Sector 6 (October 2015); Alexander Wolff, Europäische Betriebsräte nach dem Brexit, Betriebs-Berater 1784 (2016); Christoph Bode, Jan Bron, Barbara Fleckstein-Weiland, Marcus Mick and Manfred Reich, Brexit - Tax it?, Betriebs-Berater 1367 (2016); Sarah Garvey, Karen Birch and Maeve Hanna, Brexit - Legal Consequences for Commercial Parties, 3 (May 2016); Jean-Claude Piris, If the UK Votes to Leave, Centre for European Reform, January 2016, at 4.

${ }^{4}$ Marc Seeger, Die Folgen des „Brexit“ für die britische Limited mit Verwaltungssitz in Deutschland, Deutsches Steuerrecht 1817 (2016); Richard North, The Norway Option, Re-joining the EEA as an Alternative to Membership of the European Union (The Bruges Group 2013); Swati Dhingra and Thomas Sampson, Life after BREXIT: What are the UK's Options outside the European Union?, Center for Economic Performance, CEP Brexit Analysis 4 (2016); Wolfgang Münchau, Brexit: The Norway Option is the Best Available for the UK, Financial Times, 28 June 2016; Peter Spence and Szu Ping
} 
status within the EEA. The present article challenges the underlying (and often merely implicit) assumption that the UK's withdrawal from the EU will automatically result in its withdrawal from the EEA, given that the EEA Agreement is a separate international treaty subject to separate legal rules governing withdrawals and effects of possible changes in EU membership. It argues that a withdrawal from the EU will in fact not affect the UK's continuing EEA membership, ${ }^{5}$ as long as the UK does not voluntarily choose to also withdraw from the EEA. ${ }^{6}$ It then analyses the post-Brexit situation under the EEA Agreement by addressing its practical application to a number of different areas, ${ }^{7}$ as inter alia the free movement of UK companies within the EEA, the future of the 'European passport' for UK credit institutions and investment firms, as well as the free (but possibly restrictable) movement of workers in the EEA.

\section{The EEA Agreement and the United Kingdom}

The Agreement on the European Economic Area ${ }^{8}$ (EEA Agreement) was signed on 2 May 1992 and first entered into force on 1 January 1994. The EEA Agreement was subsequently amended on a number of occasions, most recently through the Agreement on the participation of Croatia in the European Economic Area of 11 April 2014. ${ }^{9}$ It is currently in force between 32 Contracting Parties, namely the EU (as successor to the European Community (EC) $)^{10}$, each of its currently 28 Member States (including the UK), and the three Member States of the European Free Trade Association (EFTA) Iceland, Liechtenstein and Norway. (In contrast, the fourth current EFTA Member State - Switzerland - is not a Contracting Party to the EEA Agreement.)

\subsection{The European Economic Area}

According to Article 1(1) of the EEA Agreement, its aim is to promote a continuous and balanced strengthening of trade and economic relations between the Contracting Parties with equal conditions of competition, and the respect of the same rules, with a view to creating a homogeneous EEA. Like the TFEU, the EEA Agreement guarantees free access to the European internal market, in particular, by establishing cer-

Chan, Safe Harbour: Why the Norway option could take the risk out of Brexit, The Telegraph, 28 June 2016.

5 See 4. below.

6 See 3. below.

7 See 5. below.

8 OJ L 1, 3 January 1994, 3.

9 OJ L 170, 11 June 2014, 5; EEA Supplement No 58, 9 October 2014, 1.

${ }_{10}$ Article 1 No. 2(b) of the Treaty of Lisbon amending the Treaty of European Union and the Treaty Establishing the European Community of 13 December 2007 (OJ C 306, 17 December 2007, 1) ('Lisbon Treaty') introduced today's Article 1(3) of the TEU, according to which the EU succeeded and replaced the EC. 
tain fundamental freedoms. ${ }^{11}$ These freedoms include the free movement of goods (Articles 8-27 of the EEA Agreement), the free movement of workers (Articles 28-30 of the EEA Agreement), the right of establishment (Articles 31-35 of the EEA Agreement), the freedom to provide services (Articles 36-39 of the EEA Agreement) and the free movement of capital (Articles 40-45 of the EEA Agreement).

In addition, legal acts of EU secondary law are incorporated into EEA law by making them part of the Annexes to the EEA Agreement. EU law referred to or contained in these Annexes or in decisions of the EEA Joint Committee ${ }^{12}$ is binding upon the EEA Contracting Parties and forms, or shall be made, part of their internal legal order (Article 7 of the EEA Agreement), a continuous task that has been aptly described as 'mirror legislation'. ${ }^{13}$ Between 1994 and 2010, 7,464 EU regulations, directives, decisions or other legal acts have been incorporated into EEA law in this manner. ${ }^{14}$

Despite the similarities just described, the EEA is marked by a significantly lesser degree of integration than the EU, and a corresponding larger degree of independence of its Member States. In the early stages of the EEA's development, the Court of Justice of the European Union (ECJ) characterised the EEA as being 'established on the basis of an international treaty which, essentially, merely creates rights and obligations as between the Contracting Parties and provides for no transfer of sovereign rights to the inter-governmental institutions which it sets up. ${ }^{15}$ More recently, the EFTA Court ${ }^{16}$ has described the EEA Agreement as 'an international treaty sui generis which contains a distinct legal order of its own', ${ }^{17}$ thereby employing an expression more similar to the ECJ's famous description of the EEC Treaty in its 1964 landmark

11 Silja Vöneky and Britta Beylage-Haarmann, Art. 217 AEUV, in Eberhard Grabitz, Meinhard Hilf and Martin Nettesheim eds, Das Recht der Europäischen Union para. 73 (56th suppl.; Munich; Beck 2015); Waldemar Hummer, Sonderbeziehung EG-EFTA, in Manfred Dauses ed, EU-Wirtschaftsrecht paras 116-118 (6th suppl.;.Munich; Beck 1997); Karin Fløistad, Fundamental Rights and the EEA Agreement, ARENA Report No 1/2004, January 2004; see also Peter-Christian Müller-Graff, EEAAgreement and EC Law: A Comparison in Scope and Content - Overview on the Basic Legal Link between Norway and the European Union, in Peter-Christian Müller-Graff and Erling Selvig eds, The European Economic Area - Norway's Basic Status in the Legal Construction of Europe, 18-20 (Berlin; Berliner Wissenschafts-Verlag 1997).

12 See in more detail about the EEA Joint Committee below at 5.2.1.

13 Carl Baudenbacher, Between Homogeneity and Independence: The Legal Position of the EFTA Court in the European Economic Area, 3 Columbia Journal of European Law 176 (1996-97); Thomas Burri and Benedikt Pirker, Constitutionalization by Association? The Doubtful Case of the European Economic Area, Yearbook of European Law 3 (2013).

14 The European Economic Area and the Single Market 20 Years on, EFTA Bulletin 42 (September 2012).

15 ECJ, Opinion 1/91 of 14 December 1991 [1991] ECR I-6079, para. 20 - EEA Agreement.

16 On the Court of Justice of the European Free Trade Association States (the 'EFTA Court'), see in more detail 5.2.2 below.

17 EFTA Court, Advisory Opinion of 10 December 1998, Case E-9/97, para. 59 - Erla María Sveinbjörnsdóttir v. Iceland; see also Takao Suami, EU Law, EEA Law and International Law - The Myth of Supranational Law and Its Implications for International Law, in The EEA and the EFTA Court 534-5 (EFTA Court ed.; Oxford and Portland; Hart 2014). 
decision Costa v. ENEL. ${ }^{18}$ In any case, there is general agreement that, in comparison to EU law, the depth of integration of the EEA Agreement is less far-reaching, ${ }^{19}$ as its legislation is less invasive and as it exempts certain business-related areas entirely. In particular, the EEA Agreement does not cover a number of the EU's policies, as e.g. the Common Agricultural Policy, the Common Fisheries Policy, the Common Trade Policy, the Common Foreign and Security Policy or Justice and Home Affairs. ${ }^{20}$

\subsection{The United Kingdom as EEA Agreement Contracting Party in its own Right}

It is an important feature of the EEA Agreement that, on the 'EU side', it neither comprises only the EU nor only its Member States as Contracting Parties, but rather the EU and each of its individual Member States. The Preamble of the EEA Agreement and the legal definition of the term 'Contracting Parties' contained therein make this entirely clear.

On the 'EU side', the EEA Agreement - in categories of EU law an association agreement in the sense of Article 217 of the TFEU' ${ }^{21}$ - was concluded as a 'mixed agreement', initially involving the then European Economic Community (EEC), the then European Community on Steel and Coal (ECSC) and all then EEC Member States as Contracting Parties. The reason why the EEA Agreement took the form of a mixed agreement, and not a 'pure' Community agreement concluded only by the $\mathrm{EEC}$ and the ECSC on the 'EU side', lies in the division of powers between the EU and its Member States under European primary law. According to the principle of conferral powers today enshrined in Article 4(1) of the TEU, the EU can solely take measures on matters for which it has been conferred power by the EU Treaties, while all other powers remain with the EU Member States. This division of powers applies also to the EU's competence to conclude international agreements under Article 216(1) of the TFEU. As the EEA Agreement also contains provisions on matters that lie beyond the EU's treaty-making power ${ }^{22}$ and belong to the competences of the

18 ECJ, Judgment of 15 July 1964, Case 6/64 [1964] ECR 585 at 593 - Costa v. ENEL: 'By contrast with ordinary international treaties, the EEC Treaty has created its own legal system'.

19 EFTA, Judgment of 28 September 2012, Case E-18/11, para. 57 - Irish Bank Resolution Corporation v. Kaupthing Bank; EFTA Court, Advisory Opinion of 10 December 1998, Case E-9/97, para. 59 - Erla María Sveinbjörnsdóttir v. Iceland; Carl Baudenbacher, The EFTA Court: Structure and Tasks, in Carl Baudenbacher ed, The Handbook of EEA Law 139 (Cham, Heidelberg, New York, Dordrecht, London; Springer, 2016).

${ }^{20}$ Peter-Christian Müller-Graff, Free Movement of Goods, in Carl Baudenbacher ed, The Handbook of EEA Law 418-9 (Cham, Heidelberg, New York, Dordrecht, London; Springer, 2016); Sven Norberg, Karin Hökborg, Martin Johansson, Dan Eliasson and Lucien Dedichen, EEA Law: A Commentary on the EEA Agreement 359 (Stockholm; Kluwer 1993).

21 Vöneky and Beylage-Haarmann, op. cit. supra n 11 at para. 73; Thomas Oppermann, Claus Dieter Classen and Martin Nettesheim, Europarecht, § 41, para. 8 (7th ed.; Munich; Beck 2016); see also Hummer, op. cit. supra $\mathrm{n} 11$ at paras 98-9.

22 Cf. Marc Bungenberg, Art. 217 AEUV, in Hans von der Groeben, Jürgen Schwarze and Armin Hatje eds, Europäisches Unionsrecht para. 26 (7th ed.; Baden-Baden; Nomos 2015). 
EU Member States, it had to be concluded as a mixed agreement. ${ }^{23}$ (Note that, in contrast, the EFTA did not become a Contracting Party to the EEA Agreement, because the EFTA is not vested with legislative competences in its own right. ${ }^{24}$ Accordingly, Iceland, Liechtenstein and Norway were able to conclude the EEA Agreement alone.)

Since the EEA Agreement entered into force in 1994, the EEC was replaced by the EC (by the Maastricht Treaty), ${ }^{25}$ the ECSC expired, with its activities and resources being absorbed by the EC (in 2002), and the EC was subsequently replaced by the EU (through the Lisbon Treaty). ${ }^{26}$ Furthermore, 16 additional Member States joined the EU over the years, ${ }^{27}$ eventually increasing the overall number to 28 . Despite this territorial extension of the EEA and - maybe more important - the gradual increase of EEC/EC/EU competences by various changes to the EEC/EC/EU Treaties, ${ }^{28}$ the EEA Agreement's structure as a mixed agreement remained unchanged.

Today, on the eve of Brexit, every EU Member State is individually a Contracting Party of the EEA Agreement, alongside the EU and the three participating EFTA States. Compliance with EEA law can therefore be claimed by and against each of them. ${ }^{29}$ The UK is also an EEA Agreement Contracting Party in its own right, and accordingly has its own rights and obligations thereunder. Put differently, the UK is not merely an EEA Member because of its membership in the EU, but because the EEA Agreement's Preamble explicitly lists the UK as a separate Contracting Party. Against this background, British companies would continue to have access to the European common market if the UK's withdrawal from the EU would leave its EEA membership undisturbed. Whether Brexit has any effect on the UK's membership in the EEA and, if yes, what kind of effect it has, cannot be answered solely on the basis

${ }^{23}$ Norberg, Hökborg, Johansson, Eliasson and Dedichen, op. cit. supra note 20 at 98.

24 Norberg, Hökborg, Johansson, Eliasson and Dedichen, op. cit. supra note 20 at 98; see also the Preamble to Protocol 35 to the EEA Agreement; Burri and Pirker, op. cit. supra note 13 at 3.

${ }^{25}$ Pursuant to Article G(a) of the Treaty on European Union, signed at Maastricht on 7 February 1992 ('Maastricht Treaty') (OJ C 191, 29 July 1992, 1), the term 'European Economic Community' was replaced by the term 'European Community'.

${ }^{26}$ See supra note 10.

27 The relevant Acts of Accession required the new EU States to also become parties to the EEA Agreement; see Article 6(5) of the Act concerning the conditions of accession of the Czech Republic, the Republic of Estonia, the Republic of Cyprus, the Republic of Latvia, the Republic of Lithuania, the Republic of Hungary, the Republic of Malta, the Republic of Poland, the Republic of Slovenia and the Slovak Republic and the adjustments to the Treaties on which the European Union is founded (OJ L 236, 23 September 2003, 3); Article 6(6) of the Protocol concerning the conditions and arrangements for admission of the republic of Bulgaria and Romania to the European Union (OJ L 157, 21 June 2005, 29); Article 6(5) of the Act concerning the conditions of accession of the Republic of Croatia (OJ L 112, 24 April 2012, 21); see also Article 5(2) of the Act concerning the conditions of accession of the Kingdom of Norway, the Republic of Austria, the Republic of Finland and the Kingdom of Sweden (OJ C 241, 29 August 1994, 21).

28 The changes to the division of powers that followed from these treaty modifications were accommodated within EEA law through Article 2(c) of the EEA Agreement; see in more detail about this provision below at 4.4.3.

${ }^{29}$ Compare Vöneky and Beylage-Haarmann, op. cit. supra n 11 at para. 22. 
of EU law, but depends primarily on the EEA Agreement that sets out the requirements for establishing and terminating an EEA membership.

\section{Possibilities to Terminate EEA Membership}

As a starting point, it is helpful to recall that the EEA Agreement was never designed as a treaty that demanded an eternal membership from its Contracting Parties, as - at least according to some - EC Treaties did prior to the Lisbon Treaty of 2007: Relying on treaty clauses providing that the European Treaties had been concluded 'for an unlimited period' (today contained in Article 53 of the TEU and Article 356 of the TFEU) ${ }^{30}$ or on the Treaties' federal or constitutional character, ${ }^{31}$ it was argued that no Member State had a right to leave the EC. ${ }^{32}$ In contrast, the EEA Agreement has always explicitly allowed for a unilateral withdrawal of any Contracting Party, should the Party so desire. ${ }^{33}$ In addition, general treaty law authorizes a termination of or withdrawal from the EEA Agreement by consent of all Contracting Parties. ${ }^{34}$

\subsection{Unilateral Voluntary Withdrawal, Article 127(1) of the EEA Agreement}

Article 127(1) of the EEA Agreement expressly sets forth the possibility for a Contracting Party to voluntarily terminate its EEA membership. According to this provision, each Contracting Party may withdraw from the EEA Agreement, provided it gives at least 12 months' notice in writing to the other Contracting Parties. The wording of the provision makes clear that the UK would be entitled to withdraw from the EEA Agreement, should it so desire. However, in the on-going discussions about Brexit the UK has never expressed a desire to do so. ${ }^{35}$ As will be demonstrated in the present article, such a withdrawal would in any case not be in the UK's best interest,

${ }^{30}$ Hans Peter Ipsen, Europäisches Gemeinschaftsrecht, 99-100 and 211 (Tübingen; Mohr Siebeck 1972); Ulrich Everling, Sind die Mitgliedstaaten der Europäischen Gemeinschaften noch Herren der Verträge?, in Völkerrecht als Rechtsordnung - Internationale Gerichtsbarkeit-Menschenrechte: Festschrift für Hermann Mosler 172 at 184 (Berlin, Heidelberg, New York; Springer 1983).

31 Jürgen Schwarze, Das allgemeine Völkerrecht in den innergemeinschaftlichen Rechtsbeziehungen, Europarecht 1 at 16 (1983); John Hill, The European Economic Community: The Right of Member State Withdrawal 12 Georgia Journal of International and Comparative Law Law 335 (1982).

32 But see Bundesverfassungsgericht (German Federal Constitutional Court), Judgment of the Second Senate of 30 June 2009 -2 BvE 2/08 et al. -, 123 Entscheidungen des Bundesverfassungsgerichts 267, para. 330 .

33 See 3.1. below.

34 See 3.2. below.

35 Some authors assume that the UK will declare a withdrawal from the EEA in order to prevent the freedom of movement for workers under the EEA Agreement from applying; see e.g. Burkhard Hess, Back to the Past: BREXIT und das europäische internationale Privat- und Verfahrensrecht 36 Praxis des Internationalen Privat- und Verfahrensrechts 418 (2016). On the free movement of workers according to Articles 28-30 of the EEA Agreement, see in more detail 5.1.2. 
as an EEA membership puts the country and its citizens in a better legal position than they would be in outside of the EEA.

This immediately raises the question whether the UK is under an obligation to also declare a withdrawal from the EEA in case it withdraws from the EU. Article 127(1) of the EEA Agreement sets out no such obligation, but by its wording ('may withdraw') merely provides an option to withdraw, leaving the use of this option entirely to each Contracting Party's discretion. It thereby stands in contrast to the neighbouring provision - the EEA Agreement's Article 128(1) - that governs applications to become a party to the EEA Agreement: Article 128(1) of the EEA Agreement indeed imposes an obligation to apply for EEA membership on all States that become EU members ('shall - apply'), ${ }^{36}$ while leaving an application to the discretion of Switzerland and other States becoming EFTA members ('may - apply'). A comparison of the two provisions therefore makes clear that no obligation to withdraw from the EEA is imposed by Article 127(1) of the EEA Agreement.

The EEA Agreement's present interpretation is furthermore supported by the fact that a possibility to expel a Member State against its will does not even exist under EU law, ${ }^{37}$ although the EU is marked by a significantly closer relationship between its members than the EEA. ${ }^{38}$ Under the current EU Treaties, the most severe sanction against a Member State is not its removal from the EU, but the rather complicated procedure under Article 7 of the TEU that can at most result in a suspension of certain rights under the Treaties, including a Member State's voting rights in the Council (Article 7(3) of the TEU). And even such a suspension of rights (that has never been used against any EU State) may only be declared in case of a Member State's serious and persistent breach of the values referred to in Article 2 of the TEU, namely respect for human dignity, freedom, democracy, equality, the rule of law and respect for human rights, including the rights of persons belonging to minorities (Article 7(2) of the TEU). In case of the UK, it has never been suggested that any breach of such fundamental values has occurred - rather, Brexit would be no more than the use of an option explicitly granted to each EU Member State by Article 50 of the TEU.

At the same time, the existence of Article 127(1) of the EEA Agreement does not necessarily mean that a voluntary withdrawal from the EEA Agreement is the only possible way for a State to lose its EEA membership. It therefore remains to be $\operatorname{seen}^{39}$

\footnotetext{
36 Adam Lazowski, EU Do Not Worry, Croatia is Behind You: A Commentary on the Seventh Accession Treaty 8 Croatian Yearbook of European Law \& Policy 1 at 33 (2012); Giulio Haas and Valentin Zellweger, Allgemeine und Schlussbestimmungen (Art. 118-129 EWR-A), in Olivier Jacot-Guillarmod ed, Accord EEE, EWR-Abkommen, EEA Agreement, 688 ( Zurich, Berne; Schulthess Polygraphischer Verlag and Verlag Stämpfli \& Cie AG, 1992); see also supra note 10.

37 See Christian Calliess, Art. 50 EUV, in Christian Calliess and Matthias Ruffert eds, EUV/AEUV: Das Verfassungsrecht der Europäisches Union mit Grundrechtecharta. Kommentar, paras 16-17 (5th ed.; Munich; Beck 2016); Juliane Kokott, Art. 356 AEUV, in Rudolf Streinz ed, EUV/AEUV, para. 6 (2nd ed; Munich; Beck 2012).

38 See 2.1 above.

39 Under 4.
} 
whether other legal rules may result in Brexit having a direct or indirect effect on the UK's Contracting Party status under the EEA Agreement.

\subsection{Treaty Termination by Consent of All Parties, Article 54(b) of the VCLT}

Alternatively, it is always possible for the EEA States to terminate the EEA Agreement - entirely, or only in relation to the UK - by consent of all Contracting Parties, including the UK, in accordance with Article 54(b) of the Vienna Convention on the Law of Treaties (VCLT) ${ }^{40}$. Article 54(b) of the VCLT sets out customary international law by stipulating that the termination of a treaty or the withdrawal of a party may take place at any time by consent of all the parties. ${ }^{41}$ The UK's EEA Membership could therefore in any case be terminated by consent of all EEA Contracting Parties as 'masters of their treaty', ${ }^{42}$ requiring an express or implicit agreement between the EU, all EU Member States as well as Iceland, Liechtenstein and Norway.

\section{Effect of Brexit on the United Kingdom's Contracting Party Status under the EEA Agreement}

Assuming that neither an express withdrawal from the EEA Agreement will be declared by the UK nor all EEA Contracting Parties will terminate the Agreement by consent, the central question remains: Does Brexit nevertheless result in the UK losing its current EEA membership? As will be demonstrated below, the answer is not easily given.

\subsection{No Specific Provision in the EEA Agreement}

The main source of uncertainty is that the EEA Agreement does not contain any specific provision addressing the effect of a EU Member State leaving the EU. As far as the wording of the original EEA Agreement of 1993 is concerned, this silence was not altogether surprising, since the EU and EC Treaties before the Lisbon Treaty of 2007 made no mention of an EU State's right to withdraw from these treaties, and the very existence of such a right was heavily disputed. ${ }^{43}$ (In spite of this, Greenland, which forms part of Denmark, had effectively withdrawn from the EEC in $1985,{ }^{44}$

\footnotetext{
40 Vienna Convention on the Law of Treaties, concluded on 23 May 1969, UN Treaties Series Vol. 1155, I-18232.

${ }^{41}$ Mark E Villiger, Commentary on the 1969 Vienna Convention on the Law of Treaties 689 (Leiden, Boston; Martinus Nijhoff, 2009); Thomas Giegerich Article 54 in Oliver Dörr and Kirsten Schmalenbach eds, Vienna Convention on the Law of Treaties, paras 8, 10, 37 (Heidelberg, Dordrecht, London, New York; Springer, 2012).

${ }^{42}$ Cf. Villiger, op. cit. supra n 41 at 686; Giegerich, op. cit. supra n 41 at para. 37.

43 See above 3.

44 Ove Johansen and Carsten Lehman Sørensen, Grönlands Austritt aus der EG 38 Europa-Archiv 399 (1983); Hans R Krämer, Greenland's European Community (EC-)Referendum, Background and
} 
albeit in an indirect manner not comparable to Brexit.) Against this background, it is understandable that the legal effects of an EC State withdrawing from the EC initially remained unaddressed in the EEA Agreement.

What is more striking is that the EEA Agreement's text also remained unchanged after Article 50 of the TEU had been introduced by the Lisbon Treaty, and a possibility of EU States withdrawing from the Union had thereby become reality. Despite this important change in EU primary law, no provision about the effect of a withdrawal from the EU on the withdrawing State's EEA membership was inserted into the EEA Agreement when the Agreement was modified on occasion of Croatia's accession to the EU. ${ }^{45}$

In light of the EEA Agreement's legislative history, the Agreement's on-going silence about the legal effect of withdrawals from the EU could be read as reflecting an intentional decision by its drafters, indicating that such a withdrawal shall have no effect on the withdrawing State's status under the EEA Agreement. Under this assumption, no further investigation would be necessary, as a post-Brexit UK would simply remain a Contracting Party to the EEA Agreement. However, it is submitted that such an interpretation hardly finds a sufficient basis in the Agreement's drafting history: As far as could be ascertained, the EEA Contracting Parties never made a conscious decision to exclude any possible effect of a withdrawal in accordance with Article 50 of the TEU on the EEA. It rather appears as if the matter was overlooked and therefore remained unaddressed after the Lisbon Treaty had been made, leaving an (unintended) gap in the EEA Agreement.

In order to fill this gap, the starting point should be an interpretation of the EEA Agreement's provisions and underlying principles as well as of the TEU and general principles of EU law, ${ }^{46}$ to which we turn next.

\subsection{No Direct Effect of the United Kingdom's Notification to Withdraw from the EU on the UK's Contracting Party Status under the EEA Agreement}

The gap just identified ${ }^{47}$ could relatively easily be filled if a notification by the UK of its intention to withdraw from the EU (Article 50(2) first sentence of the TEU) was found to have a direct effect on the UK's status as a Contracting Party under the EEA Agreement. However, an investigation of the TEU and the EEA Agreement reveals that a notification under Article 50 of the TEU has no such 'cross-treaty' effect:

\footnotetext{
Consequences 25 German Yearbook of International Law 273 (1982).

45 See supra note 9.

46 The 'considerable importance' of general principles in filling gaps within the EU legal order has inter alia been stressed by Advocate General Verica Trstenjak, Opinion of 30 June 2009, Case C-101/08, para. 68 - Audiolux and Others as well as Opinion of 8 September 2011, Case C-282/10, para. 93 Maribel Dominguez. See also Advocate General Carl Otto Lenz, Opinion of 1 December 1988, Case 359/87, para. 31 - Pietro Pinna: 'Even a gap in the rules which had arisen inadvertently would have had to be filled in a manner consistent with the system by means of judicial development of the law.'

${ }^{47}$ See 4.1 above.
} 
First, Article 50 of the TEU fails to indicate that a withdrawal from the EU would have any consequence for the withdrawing State's membership in the EEA. On the contrary, the topic of both notifications is a different one: While a notification in accordance with Article 50(2) of the TEU concerns the withdrawal from the EU (see Article 50(1) of the TEU), a notice under Article 127(1) of the EEA Agreement ${ }^{48}$ concerns a withdrawal from said Agreement. This stands in accordance with the fact that the TEU and the EEA Agreement, although closely related, still remain separate treaties. It is furthermore supported by examples in EEA-related treaty practice in which the parties explicitly provided for a 'cross-treaty effect' of withdrawals, as e.g. in the Agreement between the EFTA States on the Establishment of a Surveillance Authority and a Court of Justice (SCA) ${ }^{49}$ : According to Article 50(1) of the SCA, any EFTA State withdrawing from the EEA Agreement shall ipso facto cease to be a party to the SCA on the same day as the withdrawal takes effect. In contrast, a similar clause is neither contained in the TEU nor the EEA Agreement.

Interpreting a notification under Article 50(2) of the TEU as also resulting in a withdrawal from the EEA is furthermore excluded by the fact that the three EFTA States within the EEA - Iceland, Liechtenstein and Norway - are not parties to the TEU. From the perspective of these three EEA States, Article 50 of the TEU therefore constitutes mere 'internal law' in the sense of Article 27 of the VCLT, ${ }^{50}$ adopted by and binding on the Contracting Parties of the EEA Agreement's 'EU pillar' only. According to Article 27 of the VCLT which codifies a rule of customary law, ${ }^{51}$ '[a] party may not invoke the provisions of its internal law as justification for its failure to perform a treaty'. To the same end, Article 34 of the VCLT ${ }^{52}$ makes clear that '[a] treaty does not create either obligations or rights for a third State without its consent' (pacta tertiis nec nocent nec prosunt), thereby also preventing Iceland's, Liechtenstein's and Norway's right to trade with the UK under the conditions laid down in the EEA Agreement from being curtailed by Article 50 of the TEU.

Second, a notification of intention to withdraw from the EU cannot be interpreted as a withdrawal under Article 127(1) of the EEA Agreement because both declarations also differ in terms of their addressee and of their legal consequences. As regards the addressee, a notification of withdrawal from the EU has to be made to the Euro-

\footnotetext{
48 See already 3.1 above.

49 Agreement between the EFTA States on the Establishment of a Surveillance Authority and a Court of Justice, OJ L 344, 31 January 1994, 3 (Surveillance and Court Agreement, 'SCA').

50 See Kirsten Schmalenbach, Art. 27, in Oliver Dörr and Kirsten Schmalenbach eds, Vienna Convention on the Law of Treaties: A Commentary, para. 10 (Berlin, Heidelberg; Springer 2012).

${ }^{51}$ ICJ Certain Questions of Mutual Assistance in Criminal Matters (Djibouti v. France) (Judgment) [2008] ICJ Reports 174, para. 124; Kirsten Schmalenbach, op. cit. supra n 50 at para 4.

${ }^{52}$ It is generally recognised that Article 34 of the VCLT codifies customary law; see ECJ, Judgment of 25 February 2010, Case C-386/08 [2010] ECR I-1289, paras 42, 44 - Brita; Alexander Proelss, Art. 34, in Oliver Dörr and Kirsten Schmalenbach eds, Vienna Convention on the Law of Treaties: A Commentary, para. 4 (Berlin, Heidelberg; Springer 2012); Villiger, op. cit. supra n 41 at 472; see also ECJ, Judgment of 23 January 2014, Case C-537/11, para. 44 - Manzi and Compagnia Naviera Orchestra.
} 
pean Council, Article 50(2) first sentence of the TEU. In contrast, a notification of withdrawal from the EEA must be made 'to the other Contracting Parties' (Article 127(1) of the EEA Agreement), i.e. all other 31 Contracting Parties to the EEA Agreement. As far as the EU in its role as one of these Contracting Parties is concerned, the notification would have to be directed at the Commission that ensures the EU's external representation (Article 17(1) sixth sentence of the TEU), and not at the European Council. Accordingly, a notification of withdrawal made in accordance with Article 50(2) of the TEU would be made to an addressee different from the addressees mentioned in Article 127(1) of the EEA Agreement - as a matter of fact, not a single one of the 31 addressees to be notified under the latter provision would properly be reached by a withdrawal notification under Article 50(2) of the TEU. Already for this reason, a withdrawal from the EU cannot be regarded as a withdrawal from the EEA.

Furthermore, an interpretation of a notification under Article 50(2) of the TEU as (also) being a notice under Article 127(1) of the EEA Agreement is excluded by differences in the legal effect that both notices are aimed at: A notification in accordance with Article 127(1) of the EEA Agreement automatically leads to a termination of the declaring State's EEA membership once a 'grace period' of 12 months has passed. In contrast, a notification under Article 50(2) of the TEU does not automatically result in a withdrawal from the EU, but first triggers a pactum de negotiando $o^{53}$ requiring the $\mathrm{EU}^{54}$ to negotiate and conclude a withdrawal agreement with the withdrawing State, Article 50(2) second sentence of the TEU. Only if no such withdrawal agreement has been concluded within two years after the notification, the TEU and TFEU cease to apply to the withdrawing State, unless the European Council, in agreement with the withdrawing State, has unanimously decided to extend this period (Article 50(3) of the TEU). While the legal effect of a notification under Article 127(1) of the EEA Agreement is therefore merely deferred for 12 months, the effect of its counterpart under Article 50(2) of the TEU is both deferred for two years and conditional in nature, the event fulfilling the condition precedent being the unsuccessful outcome of the negotiations between the EU and the withdrawing EU State. These differences in legal effect make it impossible to equate one notice with the other, in particular because the notice under Article 50(2) of the TEU was designed to have (yet) no effect whatsoever at the moment the 12 months period of Article 127(1) of the EEA Agreement expires.

In summary, a future notification of the UK's intention to withdraw from the EU would have no direct effect on its EEA membership, but would leave its status as a Contracting Party to the EEA Agreement untouched.

53 Oliver Dörr, Art. 50 EUV: Austritt aus der Union, in Eberhard Grabritz, Meinhard Hilf and Martin Nettesheim eds, Das Recht der Europäischen Union, para. 15 (58th suppl.; Munich; Beck 2016).

54 Jürgen Basedow, Brexit und das Privat- und Wirtschaftsrecht 24 Zeitschrift für Europäisches Privatrecht 567, at 568 (2016) points out that Article 50(2) of the TEU leaves uncertain which of the EU's organs will conduct the negotiations. 


\subsection{Requirements of Article 128 of the EEA Agreement Not Applicable}

It furthermore has been suggested that a post-Brexit UK could only be part of the EEA by applying to become a party to the EEA Agreement in accordance with its Article $128 .{ }^{55}$ If this suggestion was correct, the hurdles for the UK trying to secure a position within the EEA would indeed be significant: For once, Article 128(1) of the EEA Agreement only envisages applications to become a Contracting Party from States that are a member of either the EU or of EFTA. As the UK would no longer be a EU State, this requirement could mean that it would first have to become an EFTA State. (Whether Article 128(1) of the EEA Agreement irreversibly excludes States that do neither belong to the EC nor EFTA from joining the EEA seems doubtful, ${ }^{56}$ as the Contracting Parties to the EEA Agreement could nevertheless decide to admit such a State by way of an agreement ratified by all Contracting Parties.) Assuming arguendo that an EFTA membership of the UK was required, its accession to the EFTA would depend on a unanimous approval by all four current EFTA States in the EFTA Council (Articles 43(2), (5) and 56(1) of the EFTA Convention) $)^{57}$, effectively resulting in a veto right for each of the EFTA States. (Norwegian government officials have in the past indicated their willingness to veto an accession by the UK.) In a second step, Article 128(2) of the EEA Agreement would require an agreement between all EEA Contracting Parties, resulting in another veto opportunity for the EU and each of the EEA States.

However, it is submitted that Article 128 of the EEA Agreement is in fact inapplicable to the UK's situation after Brexit. The reason is simple: By regulating applications by States 'to become a party to' the EEA Agreement, Article 128 only governs situations involving applicant States that are not already a Contracting Party to the EEA Agreement. The purpose of the conditions laid down in the provision is to allow the incumbent Contracting Parties to exercise control over States joining the EEA at a later time, given that additional Contracting Parties will expand the existing Contracting Parties' obligations under the Agreement. In case of the post-Brexit UK, this purpose is not at stake, as all present EEA Contracting Parties approved the UK's participation when the UK became one of the initial EEA Member States in 1994. Given that its withdrawal from the EU cannot be equated with its withdrawal from the EEA, ${ }^{58}$ Brexit would not expand the scope of the EEA Agreement to a new State as in situations envisaged by Article 128, but would merely result in a partial shift of rights and obligations under the Agreement from one present Contracting Party (the

\footnotetext{
55 House of Commons Library, Research Paper 13/42, 19; Basedow, op. cit. supra note 54 at 569; Seeger, op. cit. supra note 4, at 1817; Weller, Thomale and Benz, op. cit. supra note 3 at 2380; Wolff, op. cit. supra note 3 at 1784; Bode, Bron, Fleckstein-Weiland, Mick and Reich, op. cit. supra note 3 at 1367; Garvey, Birch and Maeve Hanna, op. cit. supra note 3 at 3.

${ }_{56}$ Compare also Basedow, op. cit. supra note 54 at 569, who suggests that Article 128(1) of the EEA Agreement would also allow applications by former EFTA States.

${ }^{57}$ Convention establishing the European Free Trade Association of 4 January 1960, as subsequently amended.

58 See 4.2 above.
} 
EU) to another present Contracting Party (the UK). Such an internal shift in competence is a matter governed by Article 2(c) of the EEA Agreement, ${ }^{59}$ and not its Article 128 .

In summary, Article 128 of the EEA Agreement does not apply to the post-Brexit UK's situation.

\subsection{Indirect Effect of the United Kingdom's Withdrawal from the EU on the UK's Contracting Party Status under the EEA Agreement?}

The points discussed above still leave room for the question whether the UK's withdrawal from the EU may have an indirect effect on the UK's Contracting Party status under the EEA Agreement, in particular because certain provisions of the EEA Agreement at first sight do not seem to allow for a Contracting Party that is neither a member of the EU nor of EFTA. This question will be addressed next.

\subsection{1. 'Two Pillar' Structure vs. Wording of the EEA Agreement}

Uncertainties surrounding the EEA Agreement's application to a post-Brexit UK are predominantly raised by the Agreement's wording. Many, if not all of its provisions were understandably drafted with the pre-Brexit situation in mind, a situation marked by all EEA Contracting Parties belonging either to the EU (respectively its predecessors) or the EFTA. Accordingly, provisions of the EEA Agreement sometimes speak only of the rights or obligations of 'EFTA States ${ }^{\prime 60}$ (a term further defined in Article 2(b) of the Agreement), and/or of 'EC Member States ' ${ }^{\prime 1}$ respectively 'the Community'. ${ }^{62}$ In doing so, they use categories that do not or no longer seem to encompass the postBrexit UK. (Similar problems do not arise under the more common provisions in the EEA Agreement that generically refer to the 'Contracting Parties'.) ${ }^{63}$

It is submitted that the appropriate solution lies in an interpretation of the EEA Agreement's terms in the light of its object and purpose, as envisaged by Article 31(1) of the VCLT. This provision is recognised as a codification of customary law ${ }^{64}$ and has frequently been applied by the ECJ in the interpretation of EC/EU association

\footnotetext{
59 See 4.4 .3 below.

${ }^{60}$ Articles 56(1)(a) and (b), 57(2)(b), 62(1)(b), 80, 81, 82(1), 83, 90(1) and (2), 99(1) and (2), 100, 101, 102(3), 108 and 116 of the EEA Agreement.

${ }_{61}$ Articles 16(1), 28, 31(1), 34, 36(1), 40, 42(2), 43, 48(1), 50(2), 51(2), 59(1), 61(1) and (2)(b), 62(1)(a) and 124 of the EEA Agreement.

${ }_{62}$ Articles 44, 90(2), 94(1) and 96(1) of the EEA Agreement.

${ }^{63}$ Articles 1(1), 3, 5, 7, 8-16, 18, 19, 21, 22, 25, 26, 29, 30, 32, 34, 36, 40, 41, 43, 45, 46, 48(2), 50(1), 51(1), 52 and 93(1) of the EEA Agreement.

${ }^{64}$ ICJ Pulp Mills on the River Uruguay (Argentina v. Uruguay) (Judgment) [2010] ICJ Reports 11, para. 65; ICJ Dispute Regarding Navigational and Related Rights (Costa Rica v. Nicaragua) (Judgment) [2009] ICJ Reports 210, para. 47; ICJ LaGrand (Germany/USA) (Judgment) [2001] ICJ Reports 463, para. 99; ICJ Kasikili/Sedudu Island (Botswana/Namibia) (Judgment) [1999] ICJ Reports 1042, para. 18; Oliver Dörr, Article 31, in Oliver Dörr and Kirsten Schmalenbach eds, Vienna Convention on the Law of Treaties: A Commentary, para. 6 (Berlin, Heidelberg; Springer 2012).
} 
agreements with third States. ${ }^{65}$ In the EEA legal order, the teleological approach to interpretation enshrined in Article 31(1) of the VCLT has even been described as the 'key interpretation method'. ${ }^{66}$

In applying this interpretative approach to the post-Brexit EEA Agreement, the appropriate starting point is the definition of the Agreement's object and purpose found in its Preamble and its Article 1(1). In this respect, the fourth recital of the Preamble speaks of 'the objective of establishing a dynamic and homogeneous European Economic Area, based on common rules and equal conditions of competition and providing for the adequate means of enforcement including at the judicial level, and achieved on the basis of equality and reciprocity and of an overall balance of benefits, rights and obligations for the Contracting Parties', while Article 1(1) of the EEA Agreement provides that ' $[\mathrm{t}$ ] he aim of this Agreement of association is to promote a continuous and balanced strengthening of trade and economic relations between the Contracting Parties with equal conditions of competition, and the respect of the same rules, with a view to creating a homogeneous European Economic Area' ${ }^{67}$ Through their focus on the 'homogeneous European Economic Area' as well as their generically framed references to 'the Contracting Parties', both provisions make clear that the EEA Agreement above all aims at establishing one single market based on equality of all Contracting Parties. To the same end, Article 4 of the EEA Agreement - a provision recognised as a cornerstone of EEA Law ${ }^{68}$ - prohibits any discrimination on grounds of nationality 'within the scope of application of this Agreement', similarly without distinguishing between different types of EEA Contracting Parties.

With this object and purpose of the EEA Agreement in mind, its provisions referring to 'EC Member States' and/or 'EFTA States' do so for one of two reasons. In some cases, this wording is used as a mere alternative expression for 'the Contracting Parties', with the respective provisions clearly intended to address all EEA States indiscriminately. ${ }^{69}$ Provisions of this type should therefore be interpreted as covering

${ }^{65}$ ECJ, Opinion 1/91 of 14 December 1991 [1991] ECR I-6079, para. 14 - EEA Agreement; ECJ, Judgment of 1 July 1993, Case C-312/91 [1993] ECR I-3751, para. 12 - Metalsa; ECJ, Judgment of 2 March 1999, Case C-416/96 [1999] ECR I-1209, para. 47 - El-Yassini; ECJ, Judgment of 20 November 2001, Case C-268/99 [2001] ECR I-8615, para. 35 - Jany and Others; ECJ, Judgment of 25 February 2010, Case C-386/08, para. 42 - Brita; see also Richard Gardiner, Treaty Interpretation 137-40 (2nd ed.; Oxford; Oxford University Press 2015).

66 Thomas Nordby and Kristoffer Nerland, Norwegian Bar, in Carl Baudenbacher ed, The Handbook of EEA Law, 313 (Cham, Heidelberg, New York, Dordrecht, London; Springer, 2016).

${ }^{67}$ Emphases added.

${ }^{68}$ Cf. EFTA Court, Judgment of 28 January 2013, Case E-16/11, para. 207 - EFTA Surveillance Authority v. Iceland ('general principle'); EFTA Court, Judgment of 25 April 2012, Case E-13/11, para. 36 - Granville Establishment v. Volker Anhalt, Melanie Anhalt and Jasmin Barbaro, née Anhalt; Halvard Haukeland Fredriksen, General Prohibition of Discrimination on Grounds of Nationality, in Carl Baudenbacher ed, The Handbook of EEA Law, 392 (Cham, Heidelberg, New York, Dordrecht, London; Springer, 2016); Olivier Jacot-Guillarmond, Préambule, objectifs et principles (art. 1er-7 EEE), in Olivier Jacot-Guillarmod ed, Accord EEE, EWR-Abkommen, EEA Agreement, 61 (Zurich, Berne; Schulthess Polygraphischer Verlag and Verlag Stämpfli \& Cie AG, 1992).

${ }^{69}$ Articles 16(1), 28, 31(1), 34, 36(1), 40, 42(2), 43, 44, 48(1), 50(2), 51(2), 59(1), 61(1) and (2) (b) and 124 of the EEA Agreement. 
all EEA States independent of their EC/EU or EFTA membership, thereby also covering a post-Brexit UK.

Other provisions ${ }^{70}$ distinguish between 'EC Member States'/'the Community' and 'EFTA States' because of the EEA Agreement's 'two-pillar structure'. ${ }^{71}$ This structure is mainly due to the making of EEA law being divided into two separate phases: In the first phase, EU law with EEA relevance is created by the EU organs, before in the second phase it is incorporated into the EEA. ${ }^{72}$ Insofar, there is indeed a difference between EEA Contracting Parties involved in the first phase, and those that are not - a distinction that the respective provisions of the EEA Agreement express by using the categories 'EC Member States'/'EFTA States', because these terms adequately categorised the EEA States at the time the Agreement was drafted. However, once Brexit has occurred, these provisions will need to be able to also capture the post-Brexit UK. Again, this is made possible by their teleological interpretation: As provisions of this type try to distinguish between, on the one hand, EEA Contracting Parties currently making or directly affected by EU legislation and, on the other hand, Contracting Parties currently only obliged to follow EU legislation once it has been incorporated into EEA Agreement's Annexes, they really aim at distinguishing between the current ,EU pillar' of the EEA and its current, non-EU pillar'. Accordingly, they should be so interpreted in light of their apparent purpose and in spite of their wording.

As a consequence, the EEA's ,non-EU pillar' is to be understood as also including the post-Brexit UK, although the term 'EFTA States' at first sight may seem to suggest otherwise.

\subsubsection{Article 126 of the EEA Agreement Does Not Hinder the Agreement's Application to a Post-Brexit United Kingdom}

The approach to the EEA Agreement's post-Brexit interpretation developed above ${ }^{73}$ also elucidates that Article 126(1) of the Agreement does not hinder its application to a post-Brexit UK, in spite of the provision's wording. Article 126(1) defines the territorial scope of the EEA Agreement ${ }^{74}$ by stipulating that ' $[\mathrm{t}]$ he Agreement shall apply to the territories to which the Treaty establishing the European Economic Community is applied and under the conditions laid down in that Treaty, and to the territories of Iceland, the Principality of Liechtenstein and the Kingdom of Norway.' At first sight, Article 126(1) could therefore be misunderstood as preventing the Agreement from applying to the UK, given that the TEEC (and its successor, the TFEU)

\footnotetext{
${ }^{70}$ Articles 56(1)(a), (b) and (c), 57(2)(b), 62(1)(a) and (b), 80, 81, 82(1), 83, 90(1) and (2), 93(2), 94(1), 95(1) and (3), 96(1), 99(1) and (2), 100, 101, 102(3), 108 and 116 of the EEA Agreement.

71 This term has frequently been used in legal commentary; see e.g. Georges Baur, Decision-Making Procedure and Implementation of New Law in Carl Baudenbacher ed, The Handbook of EEA Law, 45 at 47 (Cham, Heidelberg, New York, Dordrecht, London; Springer, 2016); Norberg, Hökborg, Johansson, Eliasson and Dedichen, op. cit. supra note 20 at 305.

72 See in more detail Baur, op. cit. supra $\mathrm{n} 71$ at $47-51$.

73 See 4.4.1 above.

${ }^{74}$ Norberg, Hökborg, Johansson, Eliasson and Dedichen, op. cit. supra note 20 at 303.
} 
will no longer be applied to the UK's territory once Brexit takes effect, and that the UK is not individually mentioned in the provision.

It is submitted that such an interpretation would misconstrue Article 126(1) of the Agreement. As a (mere) 'territorial clause', ${ }^{75}$ the provision does not in itself grant Contracting Party status, but merely specifies a single aspect of such a status that has been granted elsewhere, namely a treaty's terrorial scope of application in cases in which the treaty does not apply to one or more Contracting Parties' entire territory. As far as Iceland, Liechtenstein and Norway are concerned, Article 126(1) is therefore arguably superfluous, as it merely repeats the customary law rule that a treaty is generally binding in respect of a party's entire territory (Article 29 of the VCLT) ${ }^{76}$ In regard of the post-Brexit UK, two further reasons speak against Article 126(1) of the EEA Agreement affecting its continuing Contracting Party status: First, the legal definition of the term 'Contracting Parties' in the Preamble ${ }^{77}$ to the Agreement continues to list the UK. And second, the TEEC did apply to the UK's territory when the EEA Agreement was concluded. Denying the UK's Contracting Party status solely because of changes made within EU primary law at a later time would therefore affect Iceland's, Liechtenstein's and Norway's rights under the EEA Agreement in violation of Articles 27 and 34 of the VCLT. ${ }^{78}$

A more difficult question is whether Article 126 of the EEA Agreement will still influence the territorial scope of the EEA law's applicability within the UK after Brexit has occurred. It will be addressed separately below. ${ }^{79}$

\subsubsection{EEA Agreement Tolerates Reallocations of Competences between EU and its Member States}

Another provision of the EEA Agreement that - at least at first sight - could prevent the UK from remaining part of the EEA after Brexit is Article 2(c). This provision sets out a specific definition of the term 'Contracting Parties' as regards the EU and its Member States, i.e. the 'EU pillar' of the EEA. According to it, the term 'Contracting Parties' means, concerning the Community and the EC Member States, ${ }^{80}$ the Community and the EC Member States, or the Community, or the EC Member States. Whenever the EEA Agreement speaks of a 'Contracting Party', the term accordingly can either include the EU and its Member States cumulatively or, alternatively, only the EU or only its individual Member States. Which of these three meanings applies in each case must, according to the second sentence of Article 2(c), be deduced from

\footnotetext{
75 See Karl Doehring, The Scope of the Territorial Application of Treaties 27 Zeitschrift für ausländisches öffentliches Recht und Völkerrecht 483 (1967).

76 The situation is more complicated with respect to some of the EU States within the EEA. See therefore in more detail on Article 126(1) of the EEA Agreement and Article 29 of the VCLT 5.1.3 below.

77 See 2.2 above.

78 See already 4.2 above with more detailed reasoning.

79 See at 5.1.3.

${ }^{80}$ On the use of term 'EC Member States' (instead of 'EU Member States'), see 4.4.4.1 below.
} 
the relevant provisions of the EEA Agreement as well as from the respective competence of the EU and the EU States under the TFEU ${ }^{81}$ (formerly: the EC Treaty).

The raison d'être for Article 2(c) of the EEA Agreement is the same reason also underlying the Agreement's nature as a 'mixed agreement', ${ }^{82}$ namely the division of powers between the EU and its Member States. ${ }^{83}$ The flexible approach adopted in the provision, requiring a case-by-case assessment in light of (also) the periodically reformed EU primary law, was chosen by the EEA Contracting Parties because the division of powers was considered both as unclear in some areas and as being under constant development over time. ${ }^{84}$ In agreeing to Article 2(c), the non-EU Contracting Parties to the EEA indicated it to be unimportant for them which Contracting Party on the Agreement's 'EU side' makes certain that EEA law is being observed, as long as one Contracting Party - the one competent under the current division of powers in the EU - does.

In essence, Article 2(c) of the EEA Agreement thereby confirms that the UK remains a Contracting Party in case of Brexit: As Brexit will result in all competences that the UK had conferred upon the EU through the TEU/TFEU reverting back to the UK in their entirety, its consequences can easily be seen as governed by Article 2(c). When applied to the UK in the post-Brexit era, 'Contracting Party' would then mean the UK only, because TEU and TFEU no longer give any competence to the EU in matters concerning the UK. Since there is no indication that this case is not covered by Article 2(c) of the EEA Agreement, the Agreement's tolerant position towards reallocations of competences expressed therein supports a post-Brexit EEA Membership of the UK.

\subsubsection{EEA Agreement Tolerates Changes to Contracting Parties'Public International Law Characteristics}

Furthermore, the EEA Agreement tolerates changes to Contracting Parties' characteristics under public international law, as notably to a State's membership in supranational or international organisations like the EC or EFTA. This is already apparent from the last recital of the Agreement's preamble, which stipulates that the EEA Agreement 'does not restrict the decision-making autonomy or the treaty-making power of the Contracting Parties, subject to the provisions of this Agreement and the limitations set by public international law'.

In the past, a number of EEA Contracting Parties have indeed exercised their decision-making autonomy and treaty-making power in order to change certain of their public international law characteristics. In practice under the EEA Agreement, these changes were always taken into account in the application of EEA law, although - and this is important - the Agreement's wording had not or not yet been modified and therefore failed to reflect the changes that had taken place outside of the EEA's

\footnotetext{
${ }^{81}$ See already supra note 10 and in more detail below at 4.4.4.1.

82 See 2.2 above.

83 Norberg, Hökborg, Johansson, Eliasson and Dedichen, op. cit. supra note 20 at 98.

${ }^{84}$ Norberg, Hökborg, Johansson, Eliasson and Dedichen, op. cit. supra note 20 at 98.
} 
regime. In short, the EEA Agreement in its practical application tolerated those changes, in spite of its unchanged wording. As Article 31(3)(b) of the VCLT provides that 'any subsequent practice in the application of the treaty which establishes the agreement of the parties regarding its interpretation' shall be taken into account when interpreting a treaty, examples of such past practice are relevant in assessing Brexit's effect on the UK's EEA status.

\subsubsection{EC or EU as EEA Contracting Party?}

One example immediately becomes apparent when reading the EEA Agreement's text as currently in force: The Agreement's Preamble lists as a Contracting Party ' $[t]$ he European Community', but makes no mention whatsoever of the European Union. This is striking because ever since the Lisbon Treaty entered into force in 2009, Article 1(3) of the TEU has provided that '[t]he Union shall replace and succeed the European Community. ${ }^{95}$ Despite the fact that the EC had thereby lost its legal personality, ${ }^{86}$ the EEA Agreement remained unchanged until this very day and continues to speak of the EC as one of its Contracting Parties, as well as of 'EC Member States'. Even the Agreement on the Participation of the Republic of Croatia in the European Economic Area, ${ }^{87}$ concluded in 2014 and therefore offering an easy opportunity to amend the EEA Agreement's wording accordingly, failed to make a change. This proves that Article 1(3) of the TEU - a provision agreed upon only among the EU States and therefore not creating neither obligations nor rights for Iceland, Liechtenstein or Norway ${ }^{88}$ - was considered sufficient to apply the EEA Agreement to the EU and accept the EU's status as Contracting Party to the Agreement. In treaty practice, the EU's succession into the EC's legal position had thereby been implemented without a prior modification of the EEA Agreement's wording being viewed as indispensable.

\subsubsection{EFTA States Joining the EC}

Further examples of past practice under the EEA Agreement concern changes in Contracting Parties' EU membership, and the effect that such changes had on the application of the EEA Agreement.

The first of these changes occurred soon after the EEA Agreement had entered into force on 1 January 1994, when Austria, Finland and Sweden - all of them Contracting Parties that had been EFTA States when ratifying the Agreement-joined the EC on 1 January 1995. In spite of the suggestion by commentators that EFTA States changing from one EEA pillar to the other would simultaneously have to withdraw from the EEA Agreement in their capacity as EFTA States, and accede to the Agree-

85 See supra note 10.

${ }^{86}$ Cf. Martin Nettesheim, Art. 1 EUV in Eberhard Grabitz, Meinhard Hilf and Martin Nettesheim eds, Das Recht der Europäischen Union, para. 49-52 (48th suppl.; Munich; Beck 2012); Jean-Paul Jacqué, Art. 1 EUV in Hans von der Groeben, Jürgen Schwarze and Armin Hatje eds, Europäisches Unionsrecht, para. 18 (7th ed; Baden-Baden; Nomos 2015).

87 See supra note 9.

${ }^{88}$ See already supra notes 50-52. 
ment in their new capacity as EC States, ${ }^{89}$ Austria, Finland and Sweden withdrew from EFTA, but remained parties to the EEA Agreement, although now as members of its EU pillar. ${ }^{90}$

The EEA Agreement's wording did not reflect this change for another nine years: It was only adjusted in 2004 when the words 'the Republic of Austria', 'the Republic of Finland' and 'the Republic of Sweden' were relocated within the Preamble from their initial position after the 'and' (i.e. among the EFTA States) to their current place before the 'and' (i.e. among the EC States), and when the same words were struck from Article 126(1) of the EEA Agreement. As Austria, Finland and Sweden had already been EC Members since 1995, the EEA Agreement's wording accordingly was incorrect until 2004, because it listed them as EFTA States during this time. In the Agreement's practical application, they were nevertheless treated as EC States from 1995 onwards, with the term 'EC Member States' being read as referring to all current EC Member States.

\subsubsection{New Member States Acceding to the EC/EU}

Later accessions of Member States to the EC respectively the EU - namely by the Czech Republic, Cyprus, Estonia, Latvia, Lithuania, Hungary, Malta, Poland, Slovakia and Slovenia in 2004, by Bulgaria and Romania in 2007 and by Croatia in 2013 - were handled in a two-pronged fashion: On one hand, each new EU State became a party to the EEA Agreement in its own right, as foreseen in (and indeed demanded by) Article 128(1) of the Agreement. This participation required an agreement modifying the EEA Agreement that had to be ratified or approved by all Contracting Parties, Article 128(2) second sentence of the EEA Agreement, and that only entered into force afterwards.

On the other hand, the EC/EU in its role as a separate Contracting Party expanded by the territories of the newly acceded EC/EU States the moment their accession became effective. By virtue of Article 126(1), this expansion of the EU's territory immediately resulted in an expansion of the EEA's territorial scope, without this change being reflected in the EEA Agreement's wording. Again, practice under the Agreement had therefore accommodated changes to a Contracting Party that had taken place outside of the EEA framework, and the Agreement's unchanged wording had been interpreted accordingly.

\subsubsection{Conclusions Regarding Brexit}

The aforementioned examples demonstrate that changes to a Contracting Party's public international law characteristics have always been accepted as both admissible and binding in the EEA Agreement's application, without a modification of the Agreement's wording being necessary. It is submitted that the same must apply to a change

${ }^{89}$ In this sense Norberg, Hökborg, Johansson, Eliasson and Dedichen, op. cit. supra note 20 at 305.

90 Sven Norberg and Martin Johansson, The History of the EEA Agreement and the First Twenty Years of Its Existence in Carl Baudenbacher ed, The Handbook of EEA Law, 33 (Cham, Heidelberg, New York, Dordrecht, London; Springer, 2016). 
in the UK's EU membership, which does not result in the UK losing its status as a Contracting Party of the EEA Agreement. This is so irrespective of the fact that the EEA Agreement's wording does not explicitly recognize a category of Contracting Parties that neither form part of the EU nor of EFTA, ${ }^{91}$ that Article 126(1) defines the Agreement's territorial scope only with reference to the territories of the EC and of the EFTA States ${ }^{92}$ and that Article 128(1) exclusively lists EC and EFTA States as eligible to apply for EEA membership: In accordance with Article 31(3)(b) of the VCLT, prior actions insofar speak louder than words.

\subsection{No Right of Other EEA Contracting Parties to Suspend Operation or Terminate the EEA Agreement in Relation to the United Kingdom}

A last question concerns the possible reaction by other EEA Contracting Parties to the UK's continuing EEA membership in spite of a withdrawal from the EU: Would they have the right to suspend the EEA Agreement's operation or even terminate the Agreement in relation to the UK? Such a right, if it exists, could only follow from customary international law as codified in Articles 54-64 of the VCLT. In the context of Brexit, two possible grounds potentially giving rise to such rights could be considered: A breach of the EEA Agreement by the UK, or a fundamental change of circumstances.

Article 60(2)(a) of the VCLT entitles the parties of a treaty to suspend the treaty's operation in whole or in part or to terminate it in case of a material breach by another party. However, as already said earlier in a different context, ${ }^{93}$ it appears impossible to qualify a withdrawal from the EU as a breach of the EEA Agreement, not even an immaterial one. Article 50(1) of the TEU rather gives the UK an explicit right to withdraw from the EU, which it is free to exercise 'in accordance with its own constitutional requirements'. Given that no obligation for a Member State to remain in the EU is imposed, a withdrawal from the EU cannot be sanctioned 'by the backdoor' as a material breach of the EEA Agreement.

The doctrine of clausula rebus sic stantibus enshrined in Article 62 of the VCLT is a codification of customary international law. ${ }^{94}$ It entitles parties to terminate or withdraw from a treaty (Article 62(1) of the VCLT) or to suspend its operation (Article 62(3) of the VCLT) in case of a fundamental change of circumstances. Insofar, Article 62(1) of the VCLT, contains strict requirements that furthermore have to

\footnotetext{
91 See already 4.4.1 above.

92 See 4.4 .2 above.

93 See 3.1 above.

94 Cf. ICJ Fisheries Jurisdiction (Germany v. Iceland) (Judgment) [1973] ICJ Reports 3, para. 36; ICJ Gabčikovo-Nagymaros Project (Hungary v. Slovakia) (Judgment) [1997] ICJ Reports 3, paras 46 and 99 (Articles 60-62 of the VCLT are declaratory 'in many respects'); ECJ, Judgement of 16 June 1998, Case C-162/96 [1998] ECR I-3688, para. 24 - Racke v. Hauptzollamt Mainz; Advocate General Poiares Maduro, Opinion of 10 July 2008, Cases C-205/06 and C-249/06 [2009] ECR 1301, para. 61 Commission v. Austria and Commission v. Sweden; Villiger, op. cit. supra n 41 at 780.
} 
be interpreted narrowly. ${ }^{95}$ As a result, the practical importance of clausula rebus sic stantibus is rather low, ${ }^{96}$ although States often view it as a last resort in their desire to terminate or suspend a treaty. The decisive, but open threshold of 'fundamentality' has to be determined having regard to the specific circumstances of each case. It is substantiated, inter alia, by Article 62(1)(b) of the VCLT setting forth that the effect of the change must be radically to transform the extent of obligations still to be performed under the treaty. ${ }^{97}$ According to the ICJ in the Fisheries Jurisdiction Case, the "change must have increased the burden of the obligations to be executed to the extent of rendering the performance something essentially different from that originally undertaken. ${ }^{98}$ Beyond Article $62(1)(b)$ of the VCLT, the ICJ requires the change of circumstances to 'imperil the existence or vital development of one of the parties' 99 in order to qualify as fundamental.

When measured against this strict standard, Brexit does not constitute a fundamental change, because the EEA Agreement's core elements can still be performed. In particular, its fundamental freedoms remain applicable to all Contracting Parties, including the UK, after Brexit. ${ }^{100}$ Although the UK's withdrawal from the EU will create certain difficulties because the country's representation in organs like the EFTA Court or the EFTA Surveillance Authority requires clarification, ${ }^{101}$ these changes are of insufficient importance because they neither radically modify the obligations still to be performed under the EEA Agreement nor imperil the existence or vital development of other EEA Contracting Parties. If the Contracting Parties were to find that these (non-fundamental) changes call for an adaption of the Agreement, a formal treaty amendment would be necessary, but an adaption without the consent of all Contracting Parties would not be possible. ${ }^{102}$

Finally, the general principle expressed in Article 55 of the $\mathrm{VCLT}^{103}$ also militates against a fundamental change in case of Brexit. According to this provision, a multi-

95 ICJ Gabčikovo-Nagymaros Project (Hungary v. Slovakia) (Judgment) [1997] ICJ Reports 3, para. 104; ILC Report 1966, 2 Yearbook of International Law Commission 259, para. 9 (1966); Advocate General Poiares Maduro, Opinion of 10 July 2008, Cases C-205/06 and C-249/06 [2009] ECR I-1301, para. 61 - Commission v. Austria and Commission v. Sweden; Villiger, op. cit. supra $\mathrm{n} 41$ at 770; Wolff Heintschel von Heinegg, Treaties, Fundamental Change of Circumstances in Rüdiger Wolfrum ed, Max Planck Encyclopedia of Public International Law, para. 35 (Oxford; Oxford University Press 2006).

96 Thomas Giegerich, Art. 62 in Oliver Dörr and Kirsten Schmalenbach eds, Vienna Convention on the Law of Treaties: A Commentary, para. 7 (Berlin, Heidelberg; Springer 2012).

${ }^{97}$ Cf. Observation by the Portuguese Government to the ILC, Waldock Report $V 2$ Yearbook of International Law Commission 40 (1966); Villiger, op. cit. supra n 41 at 774.

98 ICJ Fisheries Jurisdiction (Germany v. Iceland) (Judgment) [1973] ICJ Reports 3, para. 40.

99 ICJ Fisheries Jurisdiction (Germany v. Iceland) (Judgment) [1973] ICJ Reports 3, para. 38; but see Villiger, op. cit. supra n 41 at 771.

${ }^{100}$ See on the free movement of workers (Article 28 of the EEA Agreement) 5.1.2 below and on the freedom of establishment (Article 31 of the Agreement) 5.1.1.1 below.

${ }_{101}$ See 5.2 below.

102 Cf. Giegerich, op. cit. supra n 96 at para. 6.

103 The provision reflects customary international law (Villiger, op. cit. supra n 41 at 694; see also Giegerich, op. cit. supra $\mathrm{n} 96$ at para. 14). 
lateral treaty does not terminate only because the number of its parties falls below the number necessary for its entry into force. The provision is in line with the general interest in the stability of treaties that is, in particular, manifested in the customary rule of pacta sunt servanda ${ }^{104}$ If changes in the number of parties to a treaty do not justify its termination, a single party's withdrawal from another treaty can, a fortiori and for the sake of treaty's stability, not be invoked as a ground for terminating or withdrawing from the EEA Agreement.

\section{Post-Brexit Situation under the EEA Agreement}

The following section of this article will analyse the legal situation under EEA law after Brexit. For this analysis, it will be assumed that the UK has notified the European Council of its intention to withdraw from the EU in accordance with Article 50(2) first sentence of the TEU. In addition, it will be assumed that either the two-year period of Article 50(3) of the TEU (the so-called 'sunset clause') ${ }^{105}$ has lapsed without having been unanimously extended, or that an agreement governing the arrangements for the withdrawal (Article 50(2) second sentence of the TEU) has been concluded that does not address the future of the UK's EEA membership.

\subsection{Continuing Contracting Party Status of the United Kingdom}

As described above, the UK's withdrawal from the EU in accordance with Article 50 of the TEU would not affect the UK's status as a Contracting Party to the EEA Agreement. On one hand, both the rights and the obligations arising from the Agreement for each of its Contracting Parties would accordingly continue to benefit and bind the UK. The main difference concerns the scope of EEA rights and obligations applicable to the UK: As Article 2(c) of the EEA Agreement ${ }^{106}$ would no longer apply to the UK, it would now be responsible for all rights and obligations emanating from EEA law, also for those that hitherto concerned the EC/EU. In short, the post-Brexit UK would be a 'full' Contracting Party, its legal position insofar being similar to that of the three EFTA States Iceland, Liechtenstein and Norway.

On the other hand, all rights and obligations under the EEA Agreement would continue for all other EEA Contracting Parties (the EU, the 27 remaining EU States and the three EFTA States) in relationship to the UK.

\subsubsection{Effect on Rules of European Business Law}

In outlining the effects of the UK's continuing EEA membership on rules of European business law, it is helpful to distinguish between rules contained in the EEA Agree-

\footnotetext{
${ }^{104}$ Giegerich, op. cit. supra $\mathrm{n} 96$ at para. 14.

105 Werner Meng, Artikel 50 EUV in Hans von der Groeben, Jürgen Schwarze and Armin Hatje eds, Europäisches Unionsrecht, para. 6 (7th ed.; Baden-Baden; Nomos 2015).

106 See 4.4 .3 above.
} 
ment's main text (those rules resembling EEA 'primary law') and rules contained in the various Annexes to the Agreement (resembling EEA 'secondary law').

Many of the rules applicable to European businesses found in the main text of the EEA Agreement, as notably the fundamental freedoms (Articles 8-45 of the EEA Agreement), are 'identical in substance' ${ }^{107}$ to the corresponding rules in the TFEU, although their respective wording may differ somewhat. ${ }^{108}$ UK companies doing business in the EEA would therefore continue to profit from the EEA Agreement's fundamental freedoms in mostly the same manner as they enjoyed the TFEU's fundamental freedoms prior to Brexit. At the same time, companies from other EEA States would continue to profit from the EEA Agreement's fundamental freedoms in their transaction with UK-based business partners. The resulting state of affairs will be described in more detail below, using as an example the free movement of UK companies. ${ }^{109}$ In addition, certain differences between the EU and the EEA fundamental freedoms will also be addressed, focusing on the restrictions to the free movement of workers admissible under EEA primary law. ${ }^{110}$

The wide range of European business law rules created within the EU through EU secondary law (mainly regulations or directives) would cease to be binding on the UK once Brexit takes effect. ${ }^{111}$ As far as EU directives have been implemented into UK domestic law, Articles 288(3) and 291 of the TFEU would no longer require the UK to maintain the implementing provisions and to apply them. However, as most rules of EU secondary law relevant to the EEA have been included into the Annexes of the EEA Agreement, these rules would continue to be binding on the UK by virtue of Article 7 of the Agreement, albeit in form of EEA law. The same would be true for future EU secondary law, as long as it is adopted as EEA law through an amendment of the Annexes in accordance with Article 102 of the EEA Agreement. ${ }^{12}$ In short, many of the secondary legal acts on European business law would essentially apply as before, as long and as far as they have been implemented into UK domestic law. ${ }^{113}$ Nevertheless, certain differences between EU law proper and EEA law exist,

107 See Article 6 of the EEA Agreement.

108 On the free movement of workers under the EEA Agreement, see 5.1.2 below.

109 See 5.1.1.1 below.

110 See 5.1.2 below.

111 Basedow, op. cit. supra note 54 at 570.

112 See further 5.3.2.3 below.

113 What rules of EU secondary law provenance will continue to apply within the UK after Brexit is a matter to be decided by UK law (see Basedow, op. cit. supra note 54 at 570). In case of domestic law implementing EU directives, much is to be said for an assumption in favour of these domestic laws' application (compare Alexander Thiele, Der Austritt der EU - Hintergründe und rechtliche Rahmenbedingungen eines ,Brexit', Europarecht 281 at 301-2 (2016)). The case is more difficult as far as EU regulations are concerned, because Article 288(2) of the TFEU declares regulations to be directly applicable only 'in all [EU] Member States', which a post-Brexit UK will no longer be. Accordingly, a UK law governing the post-Brexit applicability of EU regulations will be needed, which could say that the content of EU regulations shall continue to apply, unless UK law provides otherwise. 
as will be demonstrated below with respect to the European 'passport' for UK credit institutions and investment firms. ${ }^{114}$

\subsubsection{In Particular: Free Movement for United Kingdom Companies}

One important effect of the UK remaining part of the EEA after Brexit concerns companies that are incorporated in the UK under UK law (mostly as private companies limited by shares or public limited companies), but have their actual centre of administration in a different EU Member State and predominantly or exclusively carry out their business from this other State. In such a situation, the company seat principle (Sitztheorie) that is the prevailing conflict of laws approach in a number of EU States would generally result in the company's legal capacity being determined by reference to the law applicable in the place where its actual centre of administration (its 'real seat') is established. ${ }^{115}$ Despite their valid incorporation under UK law, companies with their actual centre of administration outside of the UK would therefore be denied legal capacity unless they have been reincorporated in the place of their actual centre of administration in such a way as to acquire legal capacity under the latter law. The ECJ has prevented this result by holding in landmark cases like Centros, ${ }^{116}$ Überseering ${ }^{117}$ and Inspire Art ${ }^{118}$ that the freedom of establishment under Articles 49 and 54 of the TFEU requires all EU Member States to recognise the legal capacity which a company formed in accordance with the law of another EU Member State in which it has its registered office enjoys under the law of its State of incorporation.

Some authors have argued that the cross-border mobility of UK companies resulting from their freedom of establishment under the TFEU would be lost once Brexit occurs, since Articles 49 and 54 of the TFEU no longer apply. ${ }^{119}$ As a result, inter alia limitations of liability under UK company law would no longer apply, potentially resulting in an unlimited personal liability of shareholders for company debts. ${ }^{120} \mathrm{How}-$ ever, this view overlooks that due to the UK's continuing status as a Contracting Party of the EEA Agreement, the freedom of establishment under Articles 31 and 34 of the

114 See 5.1.1.2 below.

115 See in more detail Werner F Ebke, The 'Real Seat' Doctrine in the Conflict of Corporate Laws 36 Foreign Law Year in Review 1015 (2002); Eddy Wymeersch, The Transfer of the Company's Seat in European Company Law, ECGI Working Paper Series in Law, Working Paper No. 08/2003; Nicole Rothe, Freedom of Establishment of Legal Persons Within the European Union: An Analysis of the European Court of Justice Decision in the Überseering Case 53 American University Law Review 1103 (2004).

116 ECJ, Judgment of 9 March 1999, Case C-212/97 [1999] ECR I-1459, para. 39 - Centros.

117 ECJ, Judgement of 5 November 2002, Case C-208/00 [2002] ECR I-9919, paras 94-95 - Überseering.

118 ECJ, Judgment of 30 September 2003, Case C-167/01 [2003] ECR I-512, paras 95-105 - Inspire Art.

119 Hess, op. cit. supra note 35 at 417-8; Seeger, op. cit. supra note 4, at 1819-21; Weller, Thomale and Benz, op. cit. supra note 3, at 2380; also Basedow, op. cit. supra note 54 at 570.

${ }^{120}$ Hess, op. cit. supra note 35 at 418; Seeger, op. cit. supra note 4, at 1819; Weller, Thomale and Benz, op. cit. supra note 3, at 2381. 
EEA Agreement would remain unaffected by Brexit. As the EFTA Court held in Arcade Drilling, ${ }^{121}$ Articles 31 and 34 of the EEA Agreement guarantee the crossborder mobility of companies within the EEA in the same manner as Articles 49 and 54 of the TFEU within the EU. ${ }^{122}$ Domestic courts in EU Member States, for example in Germany, ${ }^{123}$ have adopted the same interpretation of the EEA Agreement, and commentators agree. ${ }^{124}$ Accordingly, UK companies with their 'real seat' elsewhere within the EEA would remain unaffected by Brexit, as their legal capacity under UK law has to be recognised in all other EEA States due to Articles 31 and 34 of the EEA Agreement.

\subsubsection{In Particular: European 'Passport' for United Kingdom Credit Institutions and Investment Firms}

Under current EU financial markets rules, credit institutions ${ }^{125}$ and investment firms ${ }^{126}$ authorised in one EEA Member State are entitled to also carry out their business in any other EEA Member State, either by establishing a branch or by providing services. Due to these so-called 'passporting rights', ${ }^{127}$ credit institutions and investment firms ('institutions' in EU parlance) ) $^{128}$ that want to conduct activities in other EEA States are not required to obtain a domestic banking license from the host state authority,

${ }^{121}$ EFTA Court, Judgment of 3 October 2012, Case E-15/11, paras 41 and 46 - Arcade Drilling $A S$ v. Norway.

${ }^{122}$ On the 'homogeneity objective' in interpreting the freedom of establishment under the TFEU and under the EEA Agreement, see also EFTA Court, Advisory Opinion of 10 December 1998, Case E-3/98, paras 15-21 - Herbert Rainford-Towning; EFTA Court, Judgment of 1 July 2005, Case E-8/04, para. 17 - EFTA Surveillance Authority v. The Principality of Liechtenstein.

123 See Bundesgerichtshof (German Federal Supreme Court), Judgment of 19 September 2005 - II ZR 372/03, 164 Entscheidungen des Bundesgerichtshofs in Zivilsachen 148.

${ }^{124}$ Carl Baudenbacher and Dirk Buschle, Niederlassungsfreiheit für EWR-Gesellschaften nach Überseering, Praxis des Internationalen Privat- und Verfahrensrechts 26-31 (2004); Peter Kindler, Internationales Handels- und Gesellschaftsrecht in Münchener Kommentar zum Bürgerlichen Gesetzbuch, Vol. 11, para. 837 (6th ed.; Munich; CH Beck 2015); Wienand Meilicke, Die Niederlassungsfreiheit nach ,, Überseering “, Die GmbH-Rundschau 793 at 798 (2003); Wulf-Henning Roth, Niederlassungsund Dienstleistungsfreiheit: Grundregeln in Manfred Dauses ed, Handbuch des EU-Wirtschaftsrechts, para. 51 (40th suppl.; Munich; CH Beck 2015); Philipp Speitler, Right of Establishment and Freedom to Provide and Receive Services in Carl Baudenbacher ed, The Handbook of EEA Law, 459 (Cham, Heidelberg, New York, Dordrecht, London; Springer, 2016).

125 See Article 4(1) point 1 of the Regulation (EU) No 575/2013 of the European Parliament and of the Council of 26 June 2013 on prudential requirements for credit institutions and investment firms ... (OJ L 176, 27 June 2013, 1) (Credit Requirements Regulation, 'CRR').

126 See Article 4(1) point 1 of the Directive 2004/39/EC of the European Parliament and of the Council of 21 April 2004 on markets in financial instruments ... (OJ L 145, 30 April 2004, 1) (Markets in Financial Instruments Directive I, 'MiFID I').

127 Articles 33-46 of the Directive 2013/36/EU of the European Parliament and of the Council of 26 June 2013 on access to the activity of credit institutions and the prudential supervision of credit institutions and investment firms ... (OJ L 176, 27 June 2013, 338) (Capital Requirements Directive IV, 'CRD IV') as regards credit institutions; Articles 31 and 32 of the MiFID I as regards investment firms.

${ }^{128}$ Article 4(1) point 3 of the CRR. 
but only need to inform their home state regulator ${ }^{129}$ who remains primarily responsible for their supervision. With a European 'passport', an institution therefore only needs a banking license in its home state in order to gain access to the entire EEA. Domestic laws implementing European passport rules require that an institution has its place of business in the EEA, but not necessarily in the EU. ${ }^{130}$ If the post-Brexit UK remained in the EEA, British institutions would therefore continue to have passporting rights in other EEA States, and institutions from other EEA States would vice versa still have privileged access to the British financial market (inward passporting). ${ }^{131}$

Difficulties could nevertheless arise in this context, because passporting rights implicitly presuppose that (minimum) harmonized standards of financial regulation apply to all institutions concerned. ${ }^{132}$ Domestic laws therefore make a passport dependent on the foreign financial institution e.g. being 'supervised by the competent authorities of the home State in accordance with the directives issued by the European Union'. ${ }^{133}$ Whether the latter requirement is fulfilled in the UK may be doubted once Brexit has taken place: Although CRR, CRD IV and MiFID I are all EU legal acts with EEA relevance, ${ }^{134}$ only MiFID I has yet been incorporated into Annex IX of the EEA Agreement, where EU secondary law on financial services applicable in the EEA is listed. ${ }^{135}$ In contrast, the Annex mentions neither CRR nor CRD IV as being part of EEA law, and supervisory authorities of the EEA's 'non-EU pillar' accordingly do not have to act in accordance with these directives. Does this mean that UK credit institutions after Brexit - although still domiciled in an EEA State (the UK) - would no longer be supervised 'in accordance with the directives issued by the EU', thus risking to lose their passporting rights?

Subject to certain conditions, this should not be the case, with UK passporting rights remaining unaffected by Brexit. The reasons are two-fold: As far as the CRD IV is concerned, its rules have already been implemented into UK domestic law. As long as the UK legislator would leave the implementing provisions in force after Brexit, ${ }^{136}$ with UK law accordingly exceeding the requirements of the then applicable EEA law, no difficulties would arise. The situation is somewhat more complex as far

129 Articles 35(1) and 39(1) of the CRD IV regarding credit institutions; Articles 31(2) and 32(2) of the MiFID I regarding investment firms.

${ }^{130}$ See e.g. Section 53b(1) first sentence of the German Banking Act (Kreditwesengesetz); Schedule 3 point 12(1) of the British Financial Services Markets Act 2000.

131 Assuming that Schedule 3 Part II of the British Financial Markets Act 2000 setting out the requirements for the exercise of passport rights in the UK remains in force without any changes.

${ }^{132}$ Cf. Markus Möstl, Preconditions and Limits of Mutual Recognition 47 Common Market Law Review 405 at 413-8 (2010); Christine Janssens, The Principle of Mutual Recognition, 88 (Oxford; Oxford University Press 2013).

133 Section 53b(1) first sentence of the German Banking Act (Kreditwesengesetz) (translation by the authors).

134 See Francesco A Schurr and Johannes Gasser, Financial Services Law in Carl Baudenbacher ed, The Handbook of EEA Law, 667-8 (Cham, Heidelberg, New York, Dordrecht, London; Springer, 2016) on MiFID I; see also Baur, op. cit. supra note 71 at 53-6 on the notion of EEA relevance.

135 Point 31 ba of Annex IX of the EEA Agreement.

136 See in general supra $\mathrm{n} 113$. 
as CRR is concerned, because its provisions would simply cease to apply in the UK the moment Brexit takes effect, given that it is a directly applicable EU regulation (Article 288(2) of the TFEU) that did not have to and has not been implemented into UK law. The UK legislator would therefore need to make the CRR's rules a part of post-Brexit UK domestic law ${ }^{137}$ in order to guarantee an EU-equivalent standard of supervision. It could do so e.g. by declaring the CRR applicable to institutions who wish to use passporting rights (possibly offering a second 'lighter touch' regime for institutions not interested in a passport), provided that such a declaration is sufficiently clear and precise. ${ }^{138}$

Even if post-Brexit UK supervisory law would not comprise the CRD IV and/or the CRR, any refusal of foreign supervisory authorities to recognise UK institutions' passporting rights would in principle infringe EEA law, as long as the UK has at least implemented CRD I-III. ${ }^{139}$ These directives - predecessors to CRD IV and CRR - are listed in Annex IX to the EEA Agreement ${ }^{140}$ and contain the only harmonized capital requirements for credit institutions ${ }^{141}$ currently binding on non-EU EEA States. As long as CRD IV and CRR neither have been made part of EEA law nor Annex IX pertaining to capital requirements has been provisionally suspended in accordance with Article 102(4)-(6) of the EEA Agreement, ${ }^{142}$ compliance with CRD I-III must therefore be regarded sufficient for granting UK credit institutions an EEA passport.

\subsubsection{The United Kingdom and the Free Movement of Workers}

One of the most controversial political issues during the campaign preceding the referendum about Brexit was the freedom of movement for workers granted by Article 45 of the TFEU, and the resulting influx of foreign EU nationals into the UK that had resulted therefrom. Against this background, the free movement of workers under the EEA Agreement and how it can be influenced by the UK are viewed as particularly important whenever the post-Brexit UK's position within the EEA is assessed. ${ }^{143}$

\footnotetext{
137 See already supra n 113.

138 For the correct transposition of a directive into domestic law see ECJ, Judgment of 28 February 1991, Case C-131/88 [1991] ECR I-865, para. 6 - Commission v. Germany; ECJ, Judgment 30 May 1991, Case C-361/88 [1991] ECR I-2596, para. 15 - Commission v. Germany; ECJ, Judgment of 13 December 2007, Case C-418/04 [2007] ECR I-10997, para. 158 - Commission v. Ireland.

139 See for a different view in case of the incorporation of a new legal act that only defines and gives concrete expression to already existing provisions of EEA law Halvard Haukeland Fredriksen, EEA Main Agreement and Secondary EU Law Incorporated into the Annexes and Protocols in Carl Baudenbacher ed, The Handbook of EEA Law, 108-9 (Cham, Heidelberg, New York, Dordrecht, London; Springer, 2016).

140 Points 14 and 31 of Annex IX of the EEA Agreement.

141 See Articles 25(3) and 30(1) of the Directive 2006/48/EC.

${ }_{142}$ See in more detail 5.3.2.3 below.

143 See inter alia Basedow, op. cit. supra note 54 at 569.
} 


\subsubsection{Content of the Freedom of Movement for Workers under the EEA Agreement}

Much like Article 45 of the TFEU, Article 28 of the EEA Agreement provides that 'freedom of movement for workers shall be secured' among EC States and EFTA States. There is general agreement that the content of this freedom is at the outset ${ }^{144}$ to be interpreted similarly under both treaties. ${ }^{145}$ The post-Brexit UK's non-membership in regards of both the EU and the EFTA would not affect its application to the $\mathrm{UK}^{146}$ although Article 28 of the EEA Agreement speaks of free movement 'among EC Member States and EFTA States', because these terms - as outlined earlier ${ }^{147}$ are to be interpreted as referring to EU States and non-EU States within the EEA. In addition, EU secondary law on workers' free movement has been adopted as EEA law and therefore also applies to the EEA's 'non-EU pillar'. ${ }^{148}$

A partial difference between EU and EEA may result from Article 20(1) of the TFEU establishing a 'citizenship of the Union', making every person holding the nationality of an EU Member State also a citizen of the EU. Articles 20(2)(a) and 21 of the TFEU give every EU citizen the right to move and reside freely within the territory of the Member States, thereby creating a more general free movement right in addition to the free movement for workers under Article 45 of the TFEU. (As always, this right can only be exercised in accordance with the conditions and limits defined by the EU primary and secondary law. ${ }^{149}$ Nevertheless, the ECJ has based certain rights of residence directly on Article 21(1) of the TFEU.) ${ }^{150}$ In contrast, no comparable general right of free movement is granted by the EEA Agreement, because no 'EEA citizenship' exists. This is in conformity with the lesser degree of integration aimed at by the EEA's Contracting Parties. ${ }^{151}$ In spite of this difference, recent caselaw of the EFTA Court (in Clauder) ${ }^{152}$ has been interpreted by some authors as 'clearly' laying 'the substantive foundations for a comprehensive right to move and reside freely granted to all citizens of EEA countries', thereby resembling a 'EEA

${ }^{144}$ On 'safeguard measures' allowed only under the EEA Agreement, see 5.1.2.2 below.

145 ECJ, Judgment of 10 May 2012, Case C-39/10, para. 67 - Commission v. Estonia; ECJ, Judgment of 23 September 2003, Case C-452/01 [2003] ECR I-9743, paras 27-30 - Margarethe Ospelt; EFTA Court, Judgment of 26 July 2016, Case E-28/15, para. 60 - Yankuba Jabbi v. Norway; Advocate General Kokott, Opinion of 21 March 2013, Case C-431/11, para. 17 - UK v. Council; Friedl Weiss and Clemens Kaupa, European Union Internal Market Law, 149 (Cambridge; Cambridge University Press, 2014).

146 On the EEA Agreement's territorial scope of application to the post-Brexit UK, see further 5.1 .3 below.

147 See 4.4.1 above.

148 See EFTA Court, Judgment of 26 July 2011, Case E-4/11 - Clauder (on Directive 2004/38/EC of the European Parliament and of the Council of 29 April 2004 on the right of citizens of the Union and their family members to move and reside freely with the territory of the Member States [OJ L 258, 30 April 2004, 77] and its application to Liechtenstein).

149 Article 20(2) of the TFEU in fine.

${ }^{150}$ See, concerning a right of residence for third-party nationals that had no such right under Article 45 of the TFEU or under EU secondary law, ECJ, Judgment of 12 March 2014, Case C-456/12, paras $44,48,50,61-O$. and $B$.

151 See already above at 2.1 .

152 EFTA Court, Judgment of 26 July 2011, Case E-4/11, paras 33-34, 43, 46-49 - Clauder. 
citizenship, 153 - an understanding that seems doubtful, but cannot be further investigated here.

\subsubsection{Possibility for the United Kingdom to take Safeguard Measures}

In any case, there is yet another important difference between the free movement of workers under the TFEU and its counterpart under the EEA Agreement, namely the possibility granted by Article 112 of the EEA Agreement to take so-called 'safeguard measures'. According to Article 112(1), '[i]f serious economic, societal or environmental difficulties of a sectorial or regional nature liable to persist are arising, a Contracting Party may unilaterally take appropriate measures [...]' in order to limit the freedom under the EEA Agreement giving rise to such difficulties. 'Such safeguard measures shall be restricted with regard to their scope and duration to what is strictly necessary in order to remedy the situation. Priority shall be given to such measures as will least disturb the functioning of this Agreement' (Article 112(2) of the Agreement). ${ }^{154}$

The safeguard rules in Articles 112-114 of the EEA Agreement are of a defensive character, and are applied to protect an EEA State against a disproportionate effect of certain market freedoms. ${ }^{155}$ The free movement of workers within the EEA is one of those freedoms. Safeguard provisions are common in trade agreements, ${ }^{156}$ but - and this is important - no similar measures are allowed under the TFEU's freedom of movement for workers. ${ }^{157}$ Article 112 of the EEA Agreement therefore provides the UK with a possibility to regulate the influx of foreign workers in a manner unknown under the TFEU, subject to certain conditions.

With regard to the particular situation of the post-Brexit UK, it is particularly relevant that Article 112(1) of the EEA Agreement does not only allow safeguard measures in case of serious economic or environmental difficulties, but also lists 'serious societal difficulties' as a sufficient reason for such measures. As appropriate safeguard measures may furthermore be taken 'unilaterally' by one Contracting Party, no agreement with the other EEA States is needed.

In past practice under the EEA Agreement, Liechtenstein has applied safeguard measures making entry, residence and employment of citizens of other EEA States subject to prior authorisation. These restrictions were subsequently incorporated into Annex V (free movement of workers) and Annex VIII (right of establishment) of the

153 Burri and Pirker, op. cit. supra note 13 at 11-14.

154 Article 112(3) of the EEA Agreement further provides that safeguard measures shall apply with regard to all Contracting Parties. Conditions and procedures to be followed are laid down in Article 113 of the EEA Agreement.

155 Georges Baur, Suspension of Parts of the EEA Agreement: Disputes about Incorporation, Consequences of Failure to Reach Agreement and Safeguard Measures in Carl Baudenbacher ed,.The Handbook of EEA Law, 69 at 82 (Cham, Heidelberg, New York, Dordrecht, London; Springer, 2016).

156 Norberg, Hökborg, Johansson, Eliasson and Dedichen, op. cit. supra note 20 at 287.

157 Regarding the EEC Treaty Norberg, Hökborg, Johansson, Eliasson and Dedichen, op. cit. supra note 20 at 287. 
EEA Agreement. ${ }^{158}$ This could be viewed as a precedent for a possible quota system to be imposed by the UK in the future. The foreseeable counter-argument is that Liechtenstein's situation was different from that of the UK, although it is uncertain whether the undoubtable differences between the two cases prevent the UK from making use of Article 112. In addition, safeguard measures under the EEA Agreement have in the past been used by the EC, namely against the import of farmed Norwegian salmon. ${ }^{159}$

In any case, the use of safeguard measures under the EEA Agreement may come at a price. If such a measure creates an imbalance between the rights and obligations under this Agreement, Article 114(1) of the Agreement authorizes other Contracting Parties to take such proportionate 'rebalancing measures' as are strictly necessary to remedy the imbalance. Priority shall be given to such measures as will least disturb the functioning of the EEA. As a consequence, other EEA States could employ rebalancing measures towards the UK under the conditions laid down in Article 114 of the EEA Agreement.

In summary, while the conditions for the application of safeguard measures under Articles 112-114 of the EEA Agreement have been characterised as 'very strict', ${ }^{160}$ they remain significantly less strict than the TFEU's legal regime that does not allow such measures at all. Given that many terms in the EEA Agreement's relevant provisions are rather vague, disagreements about the exact conditions for safeguard measures appear likely. At the end of the day, these disagreements will only be settled before the competent courts or - maybe more desirably - through political negotiations between the EEA Contracting Parties.

\subsubsection{EEA Agreement's Territorial Scope of Application in the United Kingdom}

A rather difficult question relates to the territorial scope of application that EEA law would have within the UK once Brexit has occurred. The source of the difficulties is Article 126(1) of the EEA Agreement, the provision defining the Agreement's territorial scope already mentioned earlier. ${ }^{161}$ By stipulating that the Agreement shall apply 'to the territories to which the Treaty establishing the European Economic Community is applied and under the conditions laid down in that Treaty', Article 126(1) of the EEA Agreement today refers to Article 355 of the TFEU. ${ }^{162}$ This provision makes the TFEU's application to certain UK territories (as e.g. the Cayman Islands, the British Virgin Islands or Bermuda) subject to special arrangements ${ }^{163}$ or,

158 See in more detail Baur, op. cit. supra note 155 at 75.

159 Commission Regulation (EC) No. 2907/95 of 15 December 1995 making the release for free circulation of salmon of EEA origin conditional upon observance of a floor price (OJ L 304, 16 December 1995, 38).

${ }^{160}$ Baur, op. cit. supra note 155 at 75.

161 See above 4.4.2.

162 The EEC Treaty that Article 126(1) of the EEA Agreement still speaks of has long been replaced by the EC Treaty and later by the TFEU; see already supra notes 25-26.

163 According to Article 355(2) of the TFEU in conjunction with Annex II, the Cayman Islands, Falkland Islands, South Georgia and the South Sandwich Islands, Montserrat, Pitcairn, Saint Helena and 
with respect to others (like the Channel Islands and the Isle of Man), to conditions. ${ }^{164}$ Once Brexit has taken effect, Article 355 of the TFEU would no longer apply to the UK. Does that mean that EEA law would therefore indiscriminately apply to all UK territories, including those previously in part exempted by virtue of Article 355 of the TFEU?

The customary public international law rule enshrined in Article 29 of the VCLT ${ }^{165}$ at first sight seems to speak for a positive answer: In general, 'a treaty is binding upon each party in respect of its entire territory'. However, the provision makes clear that this rule applies only ' $[u] n l e s s$ a different intention appears from the treaty or is otherwise established'. It is submitted that in the post-Brexit situation, such a different intention indeed appears from the treaty, namely from Article 126(1) of the EEA Agreement and its limited applicability to certain UK territories that this provision has always provided for. That Article 126(1) pursues its goal by way of a reference to the TFEU is after all merely a matter of legislative technique, with 'the territories to which the [EEC Treaty] is applied and under the conditions laid down in that Treaty' being used as a shorthand description for the rather complicated provisions on the EU's territorial scope. EEA law's territorial scope was thereby aligned with that of EU law, without having to replicate the entire wording of today's Article 355 of the TFEU. Accordingly, Article 126(1) of the EEA Agreement demonstrates the Contracting Parties' intention to make EEA law's application to certain UK territories conditional on particular requirements. As Brexit merely results in a reallocation of rights and obligations arising from the EEA law between the EU and the UK, ${ }^{166}$ but does not change the content of these rights and obligations, the same must apply with respect to EEA law's territorial scope of application within the UK.

\footnotetext{
Dependencies, British Antarctic Territory, British Indian Ocean Territory, Turks and Caicos Islands, British Virgin Islands as well as Bermuda are subject to the special arrangements for association set out in Articles 198-204 of the TFEU and the 'Overseas Association Decision' (Council Decision 2013/755/ EU of 25 November 2013 on the association of the overseas countries and territories with the European Union (OJ L 344, 19 December 2013, 1).

164 See in detail Article 355(5)(b) and (c) of the TFEU in respect of the UK Sovereign Base Areas of Akrotiri and Dhekelia in Cyprus, the Channel Islands and the Isle of Man.

165 It is generally accepted that Article 29 of the VCLT codifies customary law; in this sense The Permanent Court of Arbitration, Award of 13 December 2013, PCA Case No. 2013-13, para. 220 Sanum Investments v. Lao; Villiger, op. cit. supra n 41 at 393; Kerstin Odendahl, Art. 29 in Oliver Dörr and Kirsten Schmalenbach eds, Vienna Convention on the Law of Treaties: A Commentary, para. 3 (Berlin, Heidelberg; Springer 2012); Marko Milanovic, The Spatial Dimension: Treaties and Territory in Christian J Tams, Antonios Tzanakopoulos and Andreas Zimmermann eds, Research Handbook on the Law of Treaties, 186 (Cheltenham, Northampton; Edward Elgar 2014); see also ECJ, Judgment of 27 February 2002, Case C-37/00 [2002] ECR I-2013, para. 29 - Herbert Weber.

166 See 4.4 .3 above.
} 


\subsection{Difficulties Concerning the United Kingdom's post-Brexit Membership in the EEA}

The interpretation developed above ${ }^{167}$ according to which 'Brexit' does not terminate the UK's membership in the EEA should not be misunderstood as indicating that no difficulties would be raised under the current EEA Agreement by the UK giving up its EU membership. Such difficulties would indeed arise, primarily because certain institutional arrangements in the Agreement do not explicitly envisage an EEA Contracting Party that is neither a member state of the EU nor of the EFTA. ${ }^{168}$

\subsubsection{Representation of the United Kingdom in EEA Council and EEA Joint Committee}

This is first and foremost true in case of one of the organs established by the EEA Agreement, namely the EEA Council. The EEA Council is, in particular, responsible for giving the political impetus in the implementation of the EEA Agreement and laying down the general guidelines for the EEA Joint Committee (Article 89(1) of the Agreement). According to Article 90(1), the EEA Council consists of the members of the Council of the EC and members of the EC Commission, and of one member of the Government of each of the EFTA States. As already outlined earlier, ${ }^{169}$ the provision reflects the EEA Agrement's 'two pillar' structure and aims at mirroring this structure in the EEA Council's membership. Accordingly, the term 'of each of the EFTA States' used in Article 90(1) should be read as 'of each of the Contracting Parties that do not form part of the EU', ${ }^{170}$ thereby giving the post-Brexit UK a seat in the Council. The rule in Article 90(2) of the EEA Agreement, according to which decisions by the EEA Council shall be taken by agreement between the Community, on the one hand, and the EFTA States, on the other, does not seem to create difficulties: As there presently is no legal basis for a vote by majority neither in EFTA law nor in any other rule applicable to the EEA's 'non-EU pillar', all EEA States that are not part of the EU have to be in agreement for the EEA Council to take a decision, ${ }^{171}$ including the post-Brexit UK.

The composition of the practically more important ${ }^{172}$ EEA Joint Committee is at the outset framed more openly, with Article 93(1) of the EEA Agreement providing that ' $[t]$ he EEA Joint Committee shall consist of representatives of the Contracting Parties.' The provision thereby easily covers Contracting Parties that are neither a member of the EU nor EFTA, and already on its face supports a continued representation of the post-Brexit UK in the Joint Committee. In contrast, the decision-making

\footnotetext{
167 See 4. above.

168 See already 4.4 .1 above.

169 See supra note 71.

170 See 4.4.1 above.

171 Cf. Norberg, Hökborg, Johansson, Eliasson and Dedichen, op. cit. supra note 20 at 143.

172 Burri and Pirker, op. cit. supra note 13 at 3 and 15.
} 
rule in Article 93(2) of the EEA Agreement has been worded along the same lines as its counterpart in Article 90(2), and should be interpreted accordingly.

\subsubsection{Representation of the United Kingdom in EFTA Court and EFTA Surveillance Authority}

The UK's representation in two organs charged with the interpretation and application of EEA law - the EFTA Court and the EFTA Surveillance Authority - raises more difficult questions.

\subsubsection{EFTA Court}

Within the EEA, the task of maintaining 'homogeneity' between EU law and EEA law has primarily been entrusted to the ECJ and the EFTA Court, between whom a system of cooperation and information (Article 106 of the EEA Agreement) has been established. This arrangement is (again) a result of the EEA's 'two pillar structure'173 and was chosen after the initial plan that had aimed at the creation of a single EEA Court for the entire EEA had been declared incompatible with the TEEC by the ECJ. ${ }^{174}$ It causes particular difficulties as far as the UK's post-Brexit position is concerned: Once the UK's withdrawal from the EU has automatically terminated the ECJ's jurisdiction over the UK under the TFEU, ${ }^{175}$ a solution cannot simply be found through an interpretation of the EEA Agreement to which the UK continues to be a Contracting Party, because the EFTA Court was not created by this Agreement. On the contrary, the EFTA Court is a creation of the SCA, a separate treaty between (only) Iceland, Liechtenstein and Norway (Article 1(b) in conjunction with Article 27 of the SCA), to which the UK is not (or not yet) a Contracting Party. A teleological interpretation of the term 'EFTA States' ${ }^{176}$ would not be insufficient in this matter, because the purposes of the EEA Agreement and the SCA are not identical. In addition, many among the SCA's provisions have a wording specifically tailored to the current number of Contracting Parties that would be difficult to overcome.

Accordingly, the UK would have to accede to the SCA in order to achieve a representation in the EFTA Court. Its accession would likely require an amendment to the SCA by agreement among all current SCA Contracting Parties, because Article 51 of the SCA currently only allows for an accession by EFTA States and other SCA provisions (like Article 28 providing for three judges) would also have to be adjusted to the new situation.

Should the necessary agreement with Iceland, Liechtenstein and Norway not be reached or should the UK for other reasons opt against joining the SCA, EEA law within the UK would have to be interpreted solely by British domestic courts. According to Article 6 of the EEA Agreement, British courts would have to interpret EEA rules in conformity with relevant rulings of the ECJ given prior to the date of the EEA

\footnotetext{
173 See 4.4.1 above.

174 See ECJ, Opinion 1/91 of 14 December 1991 [1991] ECR I-6079, para. 53 - EEA Agreement.

175 Articles 258-281 of the TFEU.

176 On this interpretative approach, see already 4.4.1 above.
} 
Agreement's signature (in 1992), but would be under no obligation to follow later case-law of the ECJ or the EFTA Court. Judgements by UK courts interpreting EEA law could arguably be included in the system of exchange of information under Article 106 of the EEA Agreement, as the provision's wording (which includes 'Courts of last instance of the EFTA States') is arguably amenable to be interpreted as encompassing Courts of last instance of non-EU EEA States. Finally, Article 107 of the EEA Agreement in conjunction with Protocol 34 authorises the UK to allow its courts to ask the ECJ to decide on the interpretation of EEA law - an option that has never been used in the past, ${ }^{177}$ and it appears unlikely that the UK would do so.

\subsubsection{EFTA Surveillance Authority}

The same difficulties and possible solutions just described with a view towards the UK's post-Brexit representation in the EFTA Court apply mutatis mutandis to the EFTA Surveillance Authority (ESA), the counterpart to the EU Commission. ${ }^{178}$ As the ESA was similarly not established directly by the EEA Agreement, but through Article 4 of the SCA exclusively between Iceland, Liechtenstein and Norway, the UK's representation therein would again require a respective amendment to the SCA. ${ }^{179}$ Until then, surveillance of the fulfilment of obligations under EEA Agreement (Article 109(1) of the Agreement) by and in the UK will have to be conducted by an independent ${ }^{180}$ UK domestic authority. This authority would also be responsible for ensuring the application of the competition rules in Articles 53-64 of the Agreement. Whether the provisions on the cooperation between the EU Commission and the ESA in Article 109(2)-(5) of the Agreement can be interpreted as also including their future UK counterpart is uncertain, but arguably not impossible.

\section{3. 'No Seat at the Table': The United Kingdom and Future EU Secondary Law}

One of the major disadvantages of a mere EEA membership, as opposed to an EU membership, is the lack of involvement of non-EU EEA Contracting Parties in the making of EU secondary law.

\subsubsection{The Problem}

Under the ordinary legislative procedure, EU regulations and directives are proposed by the EU Commission ${ }^{181}$ and jointly adopted by the EU Council and the EU Parliament. ${ }^{182}$ According to Article 102(1) of the EEA Agreement, EU secondary law then

\footnotetext{
177 It seems to be a rather theoretical possibility that is of merely symbolic nature, see Baudenbacher, op. cit. supra $\mathrm{n} 19$ at 152 .

178 After Brexit, the EU Commission would no longer be competent to oversee the fulfilment of obligations by the UK in accordance with Article 17(1) third sentence of the TEU and Article 258 of the TFEU.

179 Frank Büchel and Xavier Lewis, The EFTA Surveillance Authority in Carl Baudenbacher ed, The Handbook of EEA Law, 113 at 114 (Cham, Heidelberg, New York, Dordrecht, London; Springer, 2016).

180 Article 108(1) of the EEA Agreement.

181 Articles 289(1) and 294(2) of the TFEU.

182 Articles 289(1) and 294(3)-(14) of the TFEU.
} 
generally has to be made part of EEA law by way of a corresponding amendment to the Annexes to the EEA Agreement, although the non-EU EEA Contracting Parties did not have a vote during the adoption of the respective EU regulations or directives. This weakness of non-EU EEA members' position is frequently being pointed out when a post-Brexit EEA membership of the UK is discussed, often under the catchword 'no seat at the table'. ${ }^{183}$

\subsubsection{Discussion}

The fact that non-EU Contracting Parties within the EEA - including the UK after Brexit - have no decisive say in the making of those EU legal acts that 'homogenous' EEA law will later be modelled after, ranks indeed as an important difference between the position of EU States and that of 'mere' EEA States. ${ }^{184}$ Nevertheless, the discussion's primary or even exclusive focus on the decision-making process within the EU Council runs the risk of exaggerating this difference, for a number of reasons:

\subsubsection{Involvement in the Decision-Shaping Process}

First, although there is no seat for non-EU EEA States at the ministerial table of the EU Council, there is a certain involvement of these States at the drafting stage of EU secondary law (during the 'decision-shaping process') ${ }^{185}$, albeit at the (mere) expert level. To this end, Article 99(1) of the EEA Agreement provides that the EU Commission, as soon as it draws up new legislation in a field governed by the Agreement, shall informally seek advice from experts of the EFTA States (i.e. the non-EU EEA States $)^{186}$ in the same way as it seeks advice from experts of the EC Member States for the elaboration of its proposals. ${ }^{187}$ Throughout the drafting process, EEA States of the non-EU pillar are furthermore continuously to be kept informed and consulted, Article 99(2)-(4) of the EEA Agreement. While these information and consultation rights fall short of an actual vote in the adoption of a EU legal act, ${ }^{188}$ they do guarantee a certain involvement of a post-Brexit UK in the making of future EU secondary law.

183 House of Commons Foreign Affair Committee, The Future of the European Union: UK Government Policy, First Report of Session 2013-14, Volume II, 174 (London; 2013); The Law Society of England and Wales, Alternatives to the EU 2 (September 2016); CBI, Our Global Future: The Business Vision for a Reformed EU, 16 (2013); Basedow, op. cit. supra note 54 at 569; Dhingra and Sampson, op. cit. supra $\mathrm{n} 3$ at 1; Mary Dejevsky, Brexit could finally spark reform of the EU, Independent, 3 July 2016; see also Johanna Jonsdottir, Europeanization and the European Economic Area, Iceland's participation in the EU's Policy Process, 162 (London and New York; Routledge 2013); Jacques Pelkmans and Philipp Böhler, The EEA Review and Liechtenstein's Integration Strategy 25 (Centre for European Policy Studies; Brussels 2013).

${ }_{184}$ Norberg and Johansson, op. cit. supra note 90 at 41: 'major weakness of the EEA Agreement'.

185 Baur, op. cit. supra note 71 at 47.

186 See 4.4.1 above.

187 However, the EU Commission remains entirely free in deciding whether to seek advice from experts, and which experts to consult; see Norberg, Hökborg, Johansson, Eliasson and Dedichen, op. cit. supra note 20 at 136 .

${ }^{188}$ See Burri and Pirker, op. cit. supra note 13 at 15 : 'minimal possibility to influence the content of legislation to be transposed later on ...'. 


\subsubsection{Limited Influence also Under the Current TFEU}

Second, and maybe more importantly, the picture of a 'seat at the table' should not be misconstrued as individual EU States possessing a general possibility to prevent unwanted EU secondary law from being adopted. Such a 'veto' right did exist in the earlier years of the EEC/EC, when the EEC/EC Treaties then in force often required a unanimous vote in the Council. However, over the past decades the scope for decisions by the Council acting by a mere majority has gradually been expanded, most notably through the 2007 Lisbon Treaty: Today, EU regulations and directives in most areas can be adopted within the Council by a majority of the votes, thereby no longer securing a veto right for every EU State. And the more recent practice shows that the UK has been outvoted multiple times when contentious and controversial EU secondary law was adopted, although it still had its 'seat at the table'; the EU rules introducing a financial transaction tax ${ }^{189}$ and imposing a cap on bankers' bonuses ${ }^{190}$ being only two of the recent cases that come to mind. When the rights of non-EU EEA States are not compared with the rights of EC States in 1994, but rather with those of EU States in 2016, the differences may accordingly appear less pronounced.

\subsubsection{Unanimity Required in the EEA Joint Committee}

Third, the EEA Agreement itself provides non-EU EEA States with influence on the rules that are enacted in the EEA, because decisions taken by the EEA Joint Committee on amendments to the Annexes to the EEA Agreement (Article 102(1) of EEA Agreement) require a unanimous vote of all EEA States (Article 93(2) of the Agreement). ${ }^{191}$ While this requirement may not give non-EU EEA States a right to 'opt out' as such, ${ }^{192}$ the UK's possibility to avoid entirely unwanted EU rules is arguably broader under the EEA Agreement than under the TFEU.

In light of the importance of homogeneity between EU law and EEA law, ${ }^{193}$ Article 102(3)-(6) of the EEA Agreement demands all EEA States to make every effort to reach the necessary agreement, and regard 'the affected part' of an Annex as 'provisionally suspended' if the adoption of a given EU law should exceptionally meet with a persistent veto. The difficulty to determine its exact scope ${ }^{194}$ and its precise practical consequences may make such a provisional suspension particularly undesirable; until today, no suspension has ever occurred. ${ }^{195}$ In addition, the 'acquired rights' rule in Article 102(6) second sentence of the EEA Agreement ('The rights and obli-

189 See ECJ, Judgment of 30 April 2014, Case C-209/13 - UK v. Council.

190 See ECJ, Judgment of 9 December 2014, Case C-507/13 - UK v. Parliament and Council.

191 See 5.2.1 above.

192 This point is stressed by Knut Almestad, The Notion of 'Opting Out' in Carl Baudenbacher ed, The Handbook of EEA Law, 89 (Cham, Heidelberg, New York, Dordrecht, London; Springer, 2016).

193 EFTA Court, Judgment of 16 December 1994, Case E-1/94, paras 32-35 - Ravintoloitsijain Liiton Kustannus Oy Restamark; Baur, op. cit. supra note 71 at 48; Páll Hreinsson, General Principles in Carl Baudenbacher ed, The Handbook of EEA Law, 350-5 (Cham, Heidelberg, New York, Dordrecht, London; Springer, 2016).

194 See Baur, op. cit. supra note 155 at 72.

195 Baur, op. cit. supra note 155 at 73. 
gations which individuals and economic operators have already acquired under this Agreement shall remain') limits its effects to the future, thereby making a 'veto' a viable option if a new EU law should be regarded as an unacceptable change for the worse.

\subsubsection{Conclusion}

At the end of the day, the 'no seat at the table' picture may somewhat over-simplify the position of non-EU EEA States as far as future EU secondary law is concerned. While some authors have considered it 'clear that it would be extremely difficult for a major State, like the United Kingdom, in case of a withdrawal from the EU, to accept such a solution', ${ }^{196}$ the possibilities for a post-Brexit UK to exercise influence on future changes in EEA law may be greater than they at first appear. Whether the undoubtedly remaining - weaknesses in comparison with a full EU membership are too high a price to pay for Brexit remains primarily a political question, not a legal one.

\subsection{The United Kingdom and the Financial Mechanism}

Finally, the UK has agreed with all other EEA Contracting Parties on the need to reduce the economic and social disparities between the regions of the EEA, Article 115 first sentence of the EEA Agreement. This aim is pursued through financial contributions to economically weaker EEA Member States, either within the EU ${ }^{197}$ (where the funding is delivered through the European Regional Development Fund, the European Social Fund and the Cohesion Fund) or, within the EEA's non-EU pillar, through the so-called 'Financial Mechanism' (Article 116 of the EEA Agreement and Protocols 38-38c). For the period 2014-2021, the financial contributions by Iceland, Liechtenstein and Norway through the Financial Mechanism amount to EUR 1548,10 million. $^{198}$

Once the UK has withdrawn from the EU, it will no longer contribute to the EU funds mentioned above. At the same time, neither Article 116 of the Agreement nor Protocol 38c explicitly provide for an obligation of the UK to contribute to the Financial Mechanism - not surprisingly, because they were adopted when the UK was still a paying EU Member State. However, if one accepts the approach developed earlier and interprets the term 'EFTA States' as 'the EEA's current non-EU pillar', ${ }^{199}$ the

\footnotetext{
196 Norberg and Johansson, op. cit. supra note 90 at 41.

197 Articles $174-178$ of the TFEU, Articles 175-180 of the Regulation (EU, EURATOM) No 966/2012 and in particular Regulations (EU) No 1301/2013 and No 1303/2013 of the European Parliament and of the Council of 17 December 2013 (OJ L 347, 20 December 2013, 320).

198 Article 2(1) of the Protocol 38c on the EEA Financial Mechanism (2014-2021). A yet different financial contribution of the EFTA States concerns the cooperation under Articles 78-88 of the EEA Agreement, with its requirements being set out in Article 82(1) of the Agreement and Protocol 32 (for further details see Norberg, Hökborg, Johansson, Eliasson and Dedichen, op. cit. supra note 20 at 644-6).

199 See 4.4.1 above.
} 
same interpretation must apply to Article 116 of the Agreement, resulting to the postBrexit UK having to contribute to the Financial Mechanism. As the exact amount of the UK's contribution is neither fixed in Articles 115-117 of the Agreement nor in the Protocols 38-38c, it will be necessary to adjust the relevant provisions accordingly by way of an agreement among all EEA Contracting Parties.

\section{Summary and Conclusion}

The upcoming 'Brexit' raises the question what effect the UK's withdrawal from the EU will have on its membership in the EEA. As has been demonstrated in the present article, the effect is at the same time less far-reaching and less uncertain than it at first appeared: The UK will continue to be a Contracting Party of the EEA Agreement ${ }^{200}$ (unless the UK government makes a clear notification of withdrawal also from the EEA $)^{201}$, thereby largely preserving the access of UK companies to the EEA common market. As a consequence, a European 'passport' for credit institutions and investment firms based in the UK will continue to be available, subject to an ongoing conformity of UK financial market regulation with EU principles. ${ }^{202}$

While the legal difficulties caused by the UK's change from the EEA Agreement's 'EU pillar' to its 'non-EU pillar' can mostly be solved by way of a teleological interpretation of the Agreement's provisions, ${ }^{203}$ a number of treaty provisions will arguably have to be adapted, ${ }^{204}$ requiring an agreement with the other EEA or EFTA States. In any case, the EEA membership of a UK that is neither a member of the EU nor of EFTA would certainly commence a new phase in the EEA's practice, given that its non-EU pillar would be significantly expanded and that the UK's economy is much larger than those of all EFTA States combined.

A yet different type of uncertainty arises from the political factors that will inevitably influence the negotiations between the EU and the UK about their future relationship. The UK's membership in the EEA is likely to play a role in these negotiations, although the political perspectives on its relevance and desirability may differ: While representatives of the EU may view the UK's essentially continuing access to the EU internal market as an undesirable reduction of a withdrawal's deterrent effects, EEA States for whom the UK is an important trading partner may appreciate their own continuing access to the British markets. For the UK itself an ongoing EEA membership will certainly be a welcome starting point for the upcoming negotiations, and could also serve as a suitable framework for the UK's post-Brexit development of its intra-European trade.

\footnotetext{
200 See 4. and 5.1 above.

201 See 3.1 above.

202 See 5.1.1.2 above.

${ }^{203}$ See 4. above, in particularly 4.4.1.

204 See 5.2. and 5.4.
} 